Article

\title{
Design and Synthesis of Lactams Derived from Mucochloric and Mucobromic Acids as Pseudomonas aeruginosa Quorum Sensing Inhibitors
}

\author{
Basmah Almohaywi ${ }^{1,2}$, Aditi Taunk ${ }^{1}$, Daniel S. Wenholz ${ }^{1}$, Shashidhar Nizalapur ${ }^{1}$ (D), \\ Nripendra N. Biswas ${ }^{1}{ }^{1}$, Kitty K. K. Ho ${ }^{1}$, Scott A. Rice ${ }^{3}$, George Iskander ${ }^{1}$, David StC. Black ${ }^{1}$, \\ Renate Griffith ${ }^{4}$ and Naresh Kumar ${ }^{1, *}$ \\ 1 School of Chemistry, UNSW Australia, Sydney, NSW 2052, Australia; b.almohaywi@unsw.edu.au (B.A.); \\ a.taunk@unsw.edu.au (A.T.); d.wenholz@unsw.edu.au (D.S.W.); s.nizalapur@unsw.edu.au (S.N.); \\ nnathbiswas@gmail.com (N.N.B.); kitty.ho@unsw.edu.au (K.K.K.H.); g.iskander@unsw.edu.au (G.I.); \\ d.black@unsw.edu.au (D.S.B.) \\ 2 School of Pharmacy, King Khalid University, Abha 62529, Saudi Arabia \\ 3 The Singapore Centre of Environmental Life Sciences Engineering, Nanyang Technological University, \\ Singapore 639798, Singapore; RSCOTT@ntu.edu.sg \\ 4 School of Medical Science, UNSW Australia, Sydney, NSW 2052, Australia; r.griffith@unsw.edu.edu.au \\ * Correspondence: n.kumar@unsw.edu.au; Tel.: +61-29385-4698; Fax: +61-29385-6141
}

Received: 18 April 2018; Accepted: 5 May 2018; Published: 7 May 2018

\begin{abstract}
Bacterial infections, particularly hospital-acquired infections caused by Pseudomonas aeruginosa, have become a global threat with a high mortality rate. Gram-negative bacteria including P. aeruginosa employ $N$-acyl homoserine lactones (AHLs) as chemical signals to regulate the expression of pathogenic phenotypes through a mechanism called quorum sensing (QS). Recently, strategies targeting bacterial behaviour or QS have received great attention due to their ability to disarm rather than kill pathogenic bacteria, which lowers the evolutionary burden on bacteria and the risk of resistance development. In the present study, we report the design and synthesis of $N$-alkyl- and $\mathrm{N}$-aryl 3,4 dichloro- and 3,4-dibromopyrrole-2-one derivatives through the reductive amination of mucochloric and mucobromic acid with aliphatic and aromatic amines. The quorum sensing inhibition (QSI) activity of the synthesized compounds was determined against a P. aeruginosa MH602 reporter strain. The phenolic compounds exhibited the best activity with $80 \%$ and $75 \%$ QSI at $250 \mu \mathrm{M}$ and were comparable in activity to the positive control compound Fu-30. Computational docking studies performed using the LasR receptor protein of $P$. aeruginosa suggested the importance of hydrogen bonding and hydrophobic interactions for QSI.
\end{abstract}

Keywords: quorum sensing; Pseudomonas aeruginosa; lactam; mucochloric acid; mucobromic acid

\section{Introduction}

Exploring new directions to combat bacterial infections has become critically important with the rising incidence of hospital-acquired bacterial infections and the global prevalence of bacterial resistance. Traditional antibiotics are either bactericidal (kill bacteria) or bacteriostatic (inhibit the growth of bacteria) [1]. Therefore, the selective evolutionary pressures exerted by these antibiotics on microorganisms have resulted in the rise and spread of antibiotic resistance [2]. Other factors that have contributed to increased drug resistance include the expanded use of medical devices, treatments for infections in immune-compromised patients and the overuse or mishandling of antibiotics either intentionally or inadvertently [2]. Therefore, novel therapeutic approaches to combat bacterial infection and resistance are required [3]. 
Bacteria possess an adaptive intracellular mechanism that aids in their communications in a cell density-dependent manner, allowing them to synchronize gene expression as a group using a process termed quorum sensing (QS) [4]. Bacteria sense changes in their population density via the production of diffusible small molecules known as autoinducers, such as the $N$-acylated homoserine lactones (AHLs) N-(3-oxohexanoyl)-L-homoserine lactone (OHHL) $\mathbf{1}$ in Vibrio fischeri, and N-butyryl-L-homoserine lactone 2 (C4-HSL, also known as BHL) and $\mathrm{N}$-(3-oxododecanoyl)-L-homoserine lactone 3 (OdDHL, also known as 3-oxo-C12-HSL) in P. aeruginosa (Figure 1) [5].<smiles>CCCC(=O)CC(=O)NC1CCCC1=O</smiles>

1

OHHL<smiles>CCCC(=O)NC1CCOC1=O</smiles>

2

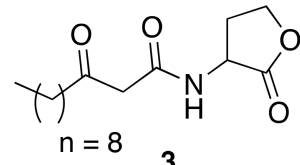

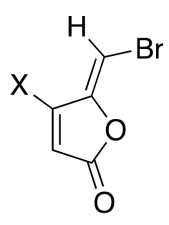

4: $\mathrm{X}=\mathrm{H}$

5: $\mathrm{X}=\mathrm{Br}$

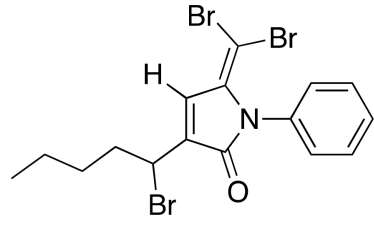

6

BHL or C4-HSL OdDHL or 3-oxo-C12-HSL

Figure 1. Bacterial $N$-acylated homoserine lactones (AHLs) used for QS and synthetic QS inhibition.

$P$. aeruginosa is an opportunistic and ubiquitous human pathogen and is amongst the most common causative agents of nosocomial and life-threatening infections [6]. In P. aeruginosa, QS is coordinated via a triumvirate of $L u x R$ homologues, namely the LasR, RhlR and QscR systems [7]. These overlapping receptors have significant roles in the regulation of gene expression and QS signals. In P. aeruginosa, QS mediates and controls the gene expressions and phenotypes responsible for its pathogenicity and resistance against the host immune system. It does so by utilizing autoinducers, which trigger the production of virulence factors (e.g., elastase, protease, pyocyanin) and biofilm formation. These phenotypes, however, are not vital to the growth of this pathogen, and thus, their inhibition does not have bacteriostatic or bactericidal effects. Hence, the interference with and antagonism of QS comprise an attractive strategy to overcome and prevent virulence and pathogenicity with minimal likelihood of resistance. Antagonists possessing the lactone head of natural AHLs, but with non-native acyl chains, represent the most extensively-studied class of synthetic QS modulators. For instance, synthetic analogues of the natural autoinducer OdDHL 3 were developed as AHL-based LasR antagonists (Figure 1) [8]. However, QS antagonists derived directly from AHLs are sensitive to enzymatic and chemical hydrolysis of the lactone ring at physiological $\mathrm{pH}$, giving ring-opened products that lack QS activity [9]. Hence, several research groups have investigated replacement of the lactone group with saturated or unsaturated cyclic and heterocyclic structures $[9,10]$.

Our research group has led the development of both fimbrolide-based analogues [11] and their lactam analogues $[12,13]$. The lactam fimbrolide analogue 6 exhibited good QS activity and was the most active lactam-based fimbrolide derivative tested against AHL-mediated signaling in Escherichia coli [13]. In line with our continuing efforts to develop new QS inhibitors, we explored the potential use of mucochloric acid 7 and mucobromic acid $\mathbf{8}$ as precursors that could provide access to functionalized lactams [14]. These compounds are inexpensive, commercially available, highly functionalized and possess multiple sites for reactivity, particularly the two halogen atoms situated across one double bond adjacent to a pseudo acid functionality. Mucohalic acids have been used for the synthesis of furanones with antibacterial and antibiofilm activities [15,16], anticancer activity [17] and anti-inflammatory activity [18]. Mucohalic acids have also been used for the synthesis of furanone-based natural products such as rubrolide [19,20], as well as their lactam analogues, showing herbicidal [20] and antibiofilm activities [15]. They have also been used as precursors of the antiseizure agent levetiracetam [21]. In this work, a library of 34 lactam compounds was prepared using the reductive amination of mucochloric and mucobromic acids with selected aliphatic and 
aromatic amines to furnish $N$-alkyl- and $N$-aryl 3,4 dichloro- and 3,4-dibromopyrrole-2-one derivatives. The QS inhibitory activities of these lactam derivatives were determined.

\section{Results}

\subsection{Chemical Synthesis}

\subsubsection{Synthesis of $N$-alkyl and $N$-aryl Lactams}

In order to generate a diverse array of lactam analogues, various amines were selected including aliphatic, arylated and heterocyclic amines. Lactams 9-31 were prepared following a literature method using sodium triacetoxyborohydride as a reducing agent in acetic acid and mucohalic acids (mucochloric acid 7 and mucobromic acid 8) (Scheme 1) [14]. Most of the products were purified easily by either trituration from methanol or flash column chromatography (ethyl acetate/hexane) (if required). Compounds with a relatively acidic functional group, such as those derived from carboxyaniline (15-16) or aminophenol (12-14), precipitated out from the reaction mixture as pure solids. Products were obtained in reasonable yields. The yields obtained are shown in Scheme 1 and were dependent on both the identity of the starting mucohalic acid and the type of functional group introduced. In general, reactions with mucochloric acid gave higher yields compared to those with mucobromic acid. The proposed mechanism for this reaction [14] depends on nucleophilic attack of the amine onto a protonated carbonyl group. The higher electrophilicity of chlorine compared to bromine facilitates this. When aliphatic groups were introduced, butylamine produced a higher percentage yield (79\%) for 9 compared to hexylamine (39\%) for 10. In the phenolic Compounds 12-14, the yield was lower when the hydroxyl group was installed on the ortho position compared to the meta and para analogues. The yields for these phenols follow the relative nucleophilicity of the nitrogen.<smiles>[X]C1=C([X])C(O)OC1=O</smiles>

7: $\mathrm{X}=\mathrm{Cl}$, mucochloric acid

8: $\mathrm{X}=\mathrm{Br}$, mucobromic acid

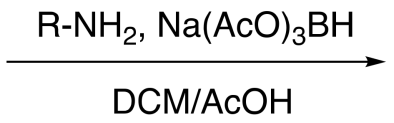

$\mathrm{DCM} / \mathrm{AcOH}$<smiles>[X]C1=C([X])C(=O)N([R])C1</smiles>

$9-31$
$9: \mathrm{X}=\mathrm{Cl}, \mathrm{R}=$ butyl, $97 \%$
10: $\mathrm{X}=\mathrm{Cl}, \mathrm{R}=$ hexyl, $39 \%$
11: $\mathrm{X}=\mathrm{Cl}, \mathrm{R}=$ benzyl, $41 \%$
12: $\mathrm{X}=\mathrm{Cl}, \mathrm{R}=2$-hydroxyphenyl, $32 \%$
13: $\mathrm{X}=\mathrm{Cl}, \mathrm{R}=3$-hydroxyphenyl, $66 \%$
14: $\mathrm{X}=\mathrm{Cl}, \mathrm{R}=4$-hydroxyphenyl, $58 \%$
15: $\mathrm{X}=\mathrm{Cl}, \mathrm{R}=3$-carboxyphenyl, $34 \%$
16: $\mathrm{X}=\mathrm{Cl}, \mathrm{R}=4$-carboxyphenyl, $98 \%$
17: $X=C l, R=3-N H B o c P h e n y l, 67 \%$
18: $X=C l, R=4-N H B o c P h e n y l, 64 \%$
19: $X=C l, R=3$-aminophenyl, $78 \%$
20: $\mathrm{X}=\mathrm{Cl}, \mathrm{R}=4$-aminophenyl, $70 \%$

21: $\mathrm{X}=\mathrm{Cl}, \mathrm{R}=$ butanoic acid, $30 \%$

22: $\mathrm{X}=\mathrm{Cl}, \mathrm{R}=1$-allyl, $36 \%$

23: $\mathrm{X}=\mathrm{Cl}, \mathrm{R}=$ phenyl, $100 \%$

24: $\mathrm{X}=\mathrm{Br}, \mathrm{R}=$ phenyl, $30 \%$

25: $X=B r, R=3$-hydroxyphenyl, $50 \%$

26: $\mathrm{X}=\mathrm{Br}, \mathrm{R}=3$-carboxyphenyl, $26 \%$

27: $\mathrm{X}=\mathrm{Br}, \mathrm{R}=4$-carboxyphenyl, $7 \%$

28: $X=B r, R=4-N H B o c p h e n y l, 36 \%$

29: $X=B r, R=4$-aminophenyl, $28 \%$

30: $X=C l, R=2-(1 \mathrm{H}$-indol-3-yl)ethyl, $42 \%$

31: $\mathrm{X}=\mathrm{Cl}, \mathrm{R}=4$-(2-ethyl)phenol, $25 \%$

Scheme 1. Reductive amination of mucochloric acid 7 and mucobromic acid 8 to generate lactam Compounds 9-31.

In the ortho derivative, the internal hydrogen bond resulted in the lower nucleophilicity of 12, which required longer reaction times. The introduction of para-carboxyphenyl (16) resulted in a higher yield compared to the meta analogue 15, suggesting the impact of the position of the electron-withdrawing group on the nucleophilicity of the aniline group. However, in the reaction of 
mucobromic acid with carboxy substituted amines, the meta-carboxyphenyl (26) produced a relatively higher yield than the para analogue (27) of $26 \%$ and $7 \%$, respectively. Furthermore, the formation of the para analogue (27) required more forcing reaction conditions by heating at $30{ }^{\circ} \mathrm{C}$ instead of room temperature. Compounds 19 and 20, and their mucobromic analogue 29, containing aminophenyl groups, were prepared from protected meta- and para-phenylenediamines via the Boc Compounds 17, 18 and 28.

Products were fully characterized using ${ }^{1} \mathrm{H}$ and ${ }^{13} \mathrm{C}$ NMR spectroscopy and high-resolution mass spectrometry. Compounds 7-31 could possibly undergo nucleophilic substitution at the vinylic carbon with the loss of a chlorine or bromine. However, high-resolution mass spectrometry confirmed the correct mass to charge ratio of the anticipated products without the loss of halogens. In ${ }^{1} \mathrm{H}$ NMR (in DMSO- $d_{6}$ ), the loss of the 5-CH and 5-hydroxyl groups, which resonate at 6.24 ppm and 8.63 ppm, respectively, for mucochloric acid and $6.21 \mathrm{ppm}$ and $8.52 \mathrm{ppm}$, respectively, for mucobromic acid confirmed the disappearance of the starting materials. Likewise, ${ }^{13} \mathrm{C}$ NMR spectra showed the disappearance of the C5 signal, which resonates at 96.76 ppm and 100.13 ppm in mucochloric and mucobromic acids, respectively. The ${ }^{1} \mathrm{H}$ NMR spectra of the products showed a distinctive singlet peak for the ring $\mathrm{C} 5$ methylene $\left(\mathrm{CH}_{2}\right)$ protons. For compounds derived from aliphatic amines including the butyl 9, hexyl 10 and allyl 22 analogues, this peak appeared at 4.01-4.03 ppm. In the tryptamine-derived Compound 30, the methylene peak appeared as a singlet at $4.30 \mathrm{ppm}$ (in DMSO- $d_{6}$ ). The methylene peak of the tyramine-derived Compound 31 (in $\mathrm{CDCl}_{3}$ ) resonated upfield at $3.81 \mathrm{ppm}$, presumably due to an electron-donating ability of these analogues. In contrast, compounds with an aromatic substituent (e.g., 12-20, 23-29) exhibited the C5 methylene protons at 4.6-4.8 ppm due to the deshielding effect of the aromatic group. The hydroxyl proton of the phenolic Compounds 12-14 was observed as a singlet at 9.5-9.8 ppm. The correct numbers of carbons were observed for Compounds 9 to 31 as assigned by ${ }^{13} \mathrm{C}$ NMR. Differences between the $N$-alkyl and $N$-aryl lactams 9-31 were also observed in the distinctive carbon C5 peaks. The C5 of the alkyl compounds resonated at $52.9 \mathrm{ppm}$, except for the $N$-allyl, which resonated at $53.4 \mathrm{ppm}$ due to the subtle deshielding effect of the allylic double bond. Compounds with $N$-aryl substituents were also characterized by their C5 peak, which resonated downfield at 53.4 ppm-55.4 ppm. Substituents on the $N$-phenyl had an effect on the resonance of C5. For example, the C5 in Compound 23 ( $N$-phenyl) resonated at 53.4 ppm, while installing the hydroxyl group at the ortho position of the $N$-phenyl resulted in a chemical shift of 55.4 ppm (Compound 12), compared to 54.0 ppm for Compound 13 (N-3-hydroxyphenyl) and 54.5 ppm for Compound 14 (N-4-hydroxy phenyl). Their mucobromic analogues 24 ( $N$-phenyl) and 25 (3-hydroxyphneyl) had a chemical shift of 57.4 ppm (supplementary materials NMR Spectra).

\subsubsection{Synthesis of Amide Analogues}

Additional amide groups were introduced into the lactam compounds to elaborate the structure-activity relationship (SAR) surrounding these compounds. We envisaged that the amide functionality might offer additional capacity to form hydrogen bonds with the biological target, the LasR receptor protein, and thus enhance quorum sensing inhibition (QSI). Therefore, the C-linked amides 32-38 and the $N$-linked amides 39-42 were targeted (Scheme 2). Mucochloric acid derivatives 16 and 20 were selected for the synthesis of the amides due to their high yields and ease of synthesis. To generate the C-linked amides, various amide coupling reagents such as 1-Ethyl-3-(3-dimethylaminopropyl)carbodiimide (EDC)/hydroxy benzotriazole (HOBT), N,N-diisopropyl ethylamine (DIPEA) and hexafluorophosphate benzotriazole tetramethyl uronium (HBTU) were used to couple the 4-carboxylphenyl mucochloric acid derivative 16 with various aliphatic amines; however, low yields of the products were obtained. Therefore, the acid 16 was instead converted to the corresponding acid chloride using $\mathrm{SOCl}_{2}$ and then reacted with the corresponding amines in the presence of triethylamine to give the target Compounds 32-38 in variable yields (Scheme 2). Difficulties in the purification of the products were the main cause for the lower yields. 
<smiles>O=C(O)c1ccc(N2CC(Cl)=C(Cl)C2=O)cc1</smiles>

16<smiles>NC(=O)c1ccc(N2CC(Cl)=C(Cl)C2=O)cc1</smiles>

$\mathrm{R}$

\section{C-Linked amides}<smiles>Nc1ccc(N2CC(Cl)=C(Cl)C2=O)cc1</smiles>

20<smiles>[R]C(=O)Nc1ccc(N2CC(Cl)=C(Cl)C2=O)cc1</smiles>

39-42
32: $R=$ butyl, $17 \%$

33: $\mathrm{R}=$ hexyl, $29 \%$

34: $\mathrm{R}=$ benzyl, $76 \%$

35: $R=2-(1 H$-indol-3-yl)ethyl, $88 \%$

36: $X=O, n=1,3 \%$

37: $X=0, n=2,50 \%$

38: $X=C, n=3,27 \%$

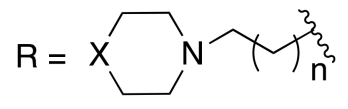

39: $\mathrm{R}=$ butyl, $31 \%$

40: $\mathrm{R}=$ hexyl, $52 \%$

41: $R=$ octanoyl, $44 \%$

42: $R=4$-bromobenzyl, $32 \%$

\section{$\mathrm{N}$-Linked amides}

Scheme 2. Reductive amination of mucochloric acid 7 and mucobromic acid 8 to generate lactam Compounds 9-31. Reagent and conditions: I, SOCl 2 ; ii, R-NH 2 , TEA, rt, THF, 24 h; iii, R-COCl, THF, TEA, rt, $24 \mathrm{~h}$.

In the ${ }^{1} \mathrm{H}$ NMR, the $\mathrm{C} 5$ methylene group was observed as a singlet at 4.88-4.91 ppm, and there were no significant changes in this peak for the C-linked amides 32-38 when compared with the precursor acid (Compound 16). The NH peak of the amides was observed as a singlet at 8.41 and 8.43 ppm for Compounds 32 and 33 containing an aliphatic chain, respectively. The amide peak of Compound 34 was observed, but overlapped with the aromatic protons at 7.21-7.46 ppm, and the NH peak of Compound 35 was observed at $10.94 \mathrm{ppm}$, presumably due to the electron-withdrawing effect of the indole moiety. The amide peak of Compounds 36 and 37 appeared as a broad signal at 8.87 and $7.91 \mathrm{ppm}$ under the aromatic protons. For Compound 38, the NH peak was observed upfield as a singlet at $5.3 \mathrm{ppm}$. Attempts to prepare amides from the acid chloride derivative of $\mathbf{1 6}$ with 2-aminothiophene, 2-aminobenzothizole, 2-aminobenzimidazole, 2-aminobenzoxazole and meta-aminopyridine were unsuccessful, giving either unreacted starting materials or intractable mixtures of products. It is possible a stronger base is needed to overcome the reduced nucleophilicity of the heterocyclic amines. To generate $N$-linked amide analogues 39-42, intermediate 20 (Scheme 2) was acylated with the appropriate acyl chloride derivatives resulting in moderate yields. The acid chloride compounds were either commercially available or made by treating the corresponding acid with thionyl chloride.

The completion of the reaction was confirmed with the disappearance of amine peak at $5.13 \mathrm{ppm}$ and the appearance of amide peaks at 9.92, 7.18, 7.24 and 10.33 ppm for Compounds 39-42 with butyl, hexyl, octyl and 4-bromobenzyl groups, respectively. 


\subsection{Biological Activity of Lactam Compounds against P. aeruginosa}

\subsubsection{QSI of Alkyl and Aryl Lactams}

The synthesized lactams were evaluated for their QSI activity following an established literature protocol [22]. In this assay, the P. aeruginosa MH602 (PAMH602) strain that expresses the luxR gene and the luxI gene and a promoter fused to the green fluorescent protein (GFP) reporter gene were used. Hence, the level of GFP fluorescence is a measure of AHL-mediated QS in this P. aeruginosa strain. The PAMH602 culture was incubated with varying concentrations $(62.5 \mu \mathrm{M}, 125 \mu \mathrm{M}$ and 250 $\mu \mathrm{M})$ of the synthesized compounds at $37^{\circ} \mathrm{C}$ for $15 \mathrm{~h}$, and the fluorescence of GFP at $\lambda=535 \mathrm{~nm}$ was determined. The optical density (OD) of the cultures at $600 \mathrm{~nm}$ was also measured to assess the effect of the compounds on bacterial growth. In these experiments, the halogenated furanone (5) (Fu-30) and another known QS antagonist (TP-5) were used as positive controls. The effects of the compounds on GFP fluorescence and OD are presented in Table 1.

Table 1. Percentage inhibition of GFP fluorescence and the reduction of OD by the synthesized lactams against $P$. aeruginosa MH602.

\begin{tabular}{|c|c|c|c|}
\hline \multicolumn{4}{|c|}{ QSI Activity against $P$. aeruginosa $\mathrm{MH602}$} \\
\hline \multicolumn{4}{|c|}{ Concentration $(\mu \mathrm{M})$} \\
\hline Compound & 250 & 125 & 62.5 \\
\hline 9 & b $71.4 \pm 1.0$ & a $51.0 \pm 1.8$ & a $47.8 \pm 0.8$ \\
\hline 10 & ${ }^{\mathrm{b}} 68.0 \pm 0.5$ & a $50.6 \pm 0.5$ & a $44.3 \pm 7.0$ \\
\hline 11 & ${ }^{\mathrm{b}} 62.1 \pm 3.4$ & a $39.4 \pm 2.5$ & a $38.2 \pm 5.0$ \\
\hline 12 & $\mathrm{~b} 83.0 \pm 2.8$ & a $82.0 \pm 2.6$ & a $69.4 \pm 0.3$ \\
\hline 13 & b $78.3 \pm 2.3$ & a $74.6 \pm 0.8$ & ${ }^{\mathrm{a}} 65.7 \pm 0.3$ \\
\hline 14 & a $58.0 \pm 3.3$ & a $47.8 \pm 1.3$ & a $35.2 \pm 5.7$ \\
\hline 15 & a $35.7 \pm 1.8$ & a $25.92 \pm 2.5$ & a $15.35 \pm 0.8$ \\
\hline 16 & a $19.8 \pm 3.3$ & a $13.25 \pm 3.9$ & a $6.85 \pm 1.8$ \\
\hline 19 & a $80.4 \pm 1.1$ & a $79.5 \pm 0.6$ & a $78.1 \pm 1.6$ \\
\hline 20 & a $58.82 \pm 5.8$ & a $36.97 \pm 3.2$ & a $22.82 \pm 3.2$ \\
\hline 21 & a $17.23 \pm 3.0$ & a $13.5 \pm 3.9$ & a $9.27 \pm 2.3$ \\
\hline 22 & a $76.4 \pm 1.2$ & a $60.5 \pm 0.5$ & a $48.2 \pm 2.0$ \\
\hline 23 & b $81.7 \pm 0.1$ & a $78.7 \pm 0.5$ & a $76.5 \pm 0.4$ \\
\hline 24 & b $80.7 \pm 3.0$ & a $77.5 \pm 4.1$ & a $69.7 \pm 0.9$ \\
\hline 25 & a $55.8 \pm 1.2$ & a $54.2 \pm 2.8$ & a $37.1 \pm 1.6$ \\
\hline 26 & a $28.17 \pm 3.1$ & a $16.25 \pm 1.9$ & a $9.23 \pm 1.1$ \\
\hline 27 & a $13.33 \pm 3.0$ & a $6.2 \pm 3.5$ & NA \\
\hline 29 & a $42.55 \pm 3.3$ & a $26.15 \pm 3.1$ & a $13.55 \pm 2.6$ \\
\hline 30 & a $74.0 \pm 1.7$ & a $43.1 \pm 1.1$ & a $32.1 \pm 3.5$ \\
\hline 31 & a $43.6 \pm 6.5$ & a $40.2 \pm 6.2$ & a $33.5 \pm 2.8$ \\
\hline 32 & a $52.5 \pm 6.2$ & a $41.7 \pm 4.1$ & NA \\
\hline 33 & a $32.3 \pm 4.6$ & a $3.5 \pm 5.8$ & NA \\
\hline 34 & a $54.2 \pm 5.9$ & a $30.9 \pm 6.0$ & a $25.3 \pm 1.0$ \\
\hline 35 & a $53.5 \pm 5.6$ & a $28.7 \pm 3.2$ & a $14.4 \pm 4.7$ \\
\hline 36 & a $33.5 \pm 0.5$ & a $20.8 \pm 2.1$ & NA \\
\hline 37 & a $37.1 \pm 2.1$ & a $29.1 \pm 2.7$ & a $4.0 \pm 1.88$ \\
\hline 38 & a $30.0 \pm 3.9$ & a $21.5 \pm 1.6$ & NA \\
\hline 39 & a $41.4 \pm 2.8$ & a $32.2 \pm 3.7$ & a $16.7 \pm 3.9$ \\
\hline 40 & a $36.0 \pm 3.0$ & a $31.7 \pm 2.0$ & ${ }^{\mathrm{a}} 4.6 \pm 0.7$ \\
\hline 41 & a $53.6 \pm 3.1$ & a $32.7 \pm 4.0$ & a $16.9 \pm 5.5$ \\
\hline 42 & a $34.5 \pm 2.0$ & a $30.2 \pm 4.4$ & a $12.2 \pm 2.9$ \\
\hline d TP-5 & a $34.4 \pm 5.2$ & a $30.4 \pm 3.2$ & a $2.3 \pm 0.3$ \\
\hline${ }^{d}$ Fu-30 (5) & c $84.8 \pm 2.9$ & c $82.5 \pm 2.5$ & ${ }^{c} 74.4 \pm 3.6$ \\
\hline
\end{tabular}

a Bacterial growth inhibition $\leq 15 \%$; ${ }^{\text {b }}$ growth inhibition between 15 and $30 \%{ }^{c}$ growth inhibition greater than $30 \%$; $\mathrm{d}$ positive control; \pm the standard deviation of the mean for three independent experiments. In each independent experiment, compounds were tested in triplicate. NA = no activity and no growth inhibition (supplementary materials Table S1). 
The QS inhibition assay indicated that the synthesized lactams displayed promising QSI activity. Compounds 9, 12-13, 19, 22-24 and $\mathbf{3 0}$ exhibited the highest QSI of $71.4-83.0 \%$ at $250 \mu \mathrm{M}$. The most active compound, the ortho-hydroxyphenyl mucochloric analogue 12, reduced GFP fluorescence by $83 \%$ $( \pm 2.8)$ at $250 \mu \mathrm{M}$ and was comparable in potency to the positive control 5 and better in activity than the triphenyl antagonist (TP-5). The QSI activity of $\mathbf{1 2}$ was well maintained at lower concentrations, with $82.0 \%( \pm 2.6)$ and $69.4 \%( \pm 0.3)$ inhibitions at $125 \mu \mathrm{M}$ and $62.5 \mu \mathrm{M}$, respectively. There was a slight reduction in activity although not significant $(78 \pm 2.3 \%$ at $250 \mu \mathrm{M}, p>0.05)$ as the phenol group moved to the meta position as in derivative 13. The para-phenolic lactam 14 was the least active $(58.0 \pm 3.3 \%$ at $250 \mu \mathrm{M}, p<0.001$ ) when compared to its ortho (12) and meta (13) counterparts, suggesting the importance of the position of the phenolic hydroxyl group on activity. Interestingly, no significant difference $(p>0.05)$ in activity was observed when comparing Compound 12 with other potent $N$-aryl analogues including Compound $19(80.4 \pm 1.1 \%)$ and Compound $23(81.7 \pm 0.1 \%)$ containing the $N$-3-aminophenyl and $N$-phenyl groups, respectively, which both exhibited high inhibition at $250 \mu \mathrm{M}$. Furthermore, the activity of Compounds $\mathbf{1 9}$ and $\mathbf{2 3}$ was also retained at lower concentrations, giving a high percentage of inhibition of $78.1 \%( \pm 1.6)$ and $76.5 \%( \pm 0.4)$ at $62.5 \mu \mathrm{M}$, respectively.

Compound 20 containing a 4-aminophenyl group was less active compared to the meta-amino phenyl analogue 19. These observations from both the $N$-phenolic and the $N$-aminophenyl compounds indicate the importance of the position of the electron donating groups installed on the $N$-phenyl ring of the lactam, with both para-substituted compounds showing reduced activity. Activity was also retained with the mucobromic analogue $24(80.7 \pm 3.0 \%$ at $250 \mu \mathrm{M})$, suggesting that both of the dichloroand dibromo-pyrrolone were acceptable for activity for this type of scaffold. The $N$-carboxyphenyl lactams including Compounds 15-16 and Compound $\mathbf{2 1}$ ( $N$-butanoic acid group), both derived from mucochloric acid, were less active compared to other $N$-aryl lactams. The position of the carboxyl group did not improve the activity, and the same was observed with their mucobromic analogues 26 and 27 , which were even less active.

The $N$-alkyl compounds were relatively less active compared to the $N$-aryl compounds. Compounds 9 and 22 containing $N$-butyl and $N$-allyl groups possessed QSI activity $(71.4 \pm 1.0 \%$ and $76.4 \pm 1.2 \%$ at $250 \mu \mathrm{M}$, respectively), but their activity was poor at lower concentrations. Moreover, adding two carbon atoms to the butyl chain of Compound $\mathbf{9}$ to give the $\mathrm{N}$-hexyl lactam 10 showed a reduction in activity $(68.0 \pm 0.5 \%$ at $250 \mu \mathrm{M})$. Compound 30, containing the $N$-2-(1H-indol-3-yl)ethyl substituent had QSI activity $(74 \pm 1.7 \%$ at $250 \mu \mathrm{M})$, but the activity dropped at lower concentrations $(32.1 \pm 3.5 \%$ at $62.5 \mu \mathrm{M})$.

\subsubsection{QSI of C-Linked and N-Linked Amide Analogues}

In general, amides 32-42 displayed only low to moderate activity, as their QSI activity reduced by $30-54 \%$ at $250 \mu \mathrm{M}$, with low to no activity at $62.5 \mu \mathrm{M}$. The C-linked amides $32-38$ were generally more active than the $N$-linked amides 39-42. This indicates the possible importance of the position or the orientation of the amide group. The C-linked amides had higher activity, which ranges from $30-53.5 \%$ inhibition at $250 \mu \mathrm{M}$ when compared to their parent acid lactam 16 (QSI $=19.8 \% \pm 3.3$ at $250 \mu \mathrm{M})$. Compounds 32 and 34 had a moderate QSI of 52.5\% $( \pm 6.2)$ and $54.2 \%( \pm 5.9)$, respectively. A comparison of the $N$-linked amides to their parent 4-aminophenyl lactam 20 (QSI $=58.8 \% \pm 5.8$ at $250 \mu \mathrm{M}$ ) showed reduced QSI activity of these amides, which ranges from $53.6-34.5 \%$. The octyl group produced inhibition of $53.6 \%( \pm 3.1)$, which was relatively higher than the butyl and hexyl groups.

\subsubsection{Evaluation of Growth Inhibition}

To ensure that the decrease in GFP fluorescence was related to QS inhibition and not a result of toxicity or a decline in the population of the bacteria, the OD of the cultures were also measured and the degree of growth inhibition noted along with the QS inhibition data in Table 1 (full results are presented in the Supplementary Information). Overall, our synthesized library of lactams displayed low growth inhibition against $P$. aeruginosa. At $62.5 \mu \mathrm{M}$, all synthesized compounds had little to no 
effect on the growth of bacteria. Although the synthesized compounds have minimal effect on bacterial growth, it should be noted that there may be other factors that can affect the QS activity [23]. The best compounds in this study and TP-5 reduced bacterial growth by less than $30 \%$, whereas the positive control compound Fu-30 (5) inhibited P. aeruginosa growth by $84 \%$ at $250 \mu \mathrm{M}$. Therefore, this study showed that the tested compounds inhibit QS with minimal effect on the growth of P. aeruginosa.

\subsubsection{Pyocyanin Inhibition}

The virulence factor pyocyanin is produced when cell density is high in response to the AHL molecule interacting with LasR. Since LasR is one of the determinant factors for the production of pyocyanin in P. aeruginosa [24], the ability of our compounds to inhibit pyocyanin production was investigated. Wild-type P. aeruginosa (PAO1) were grown in the presence of Compounds 12, 13, 19, 23 and 24, and the amount of pyocyanin in the culture supernatants was quantified based on its absorbance at $695 \mathrm{~nm}$ following a reported protocol [25]. The ability of the compounds to reduce pyocyanin levels was determined with respect to the levels of pyocyanin in the DMSO-treated positive control (Figure 2). Growth inhibition at $\mathrm{OD}_{600}$ was monitored, and the compounds showed moderate reduction in bacterial growth (22-30\%).

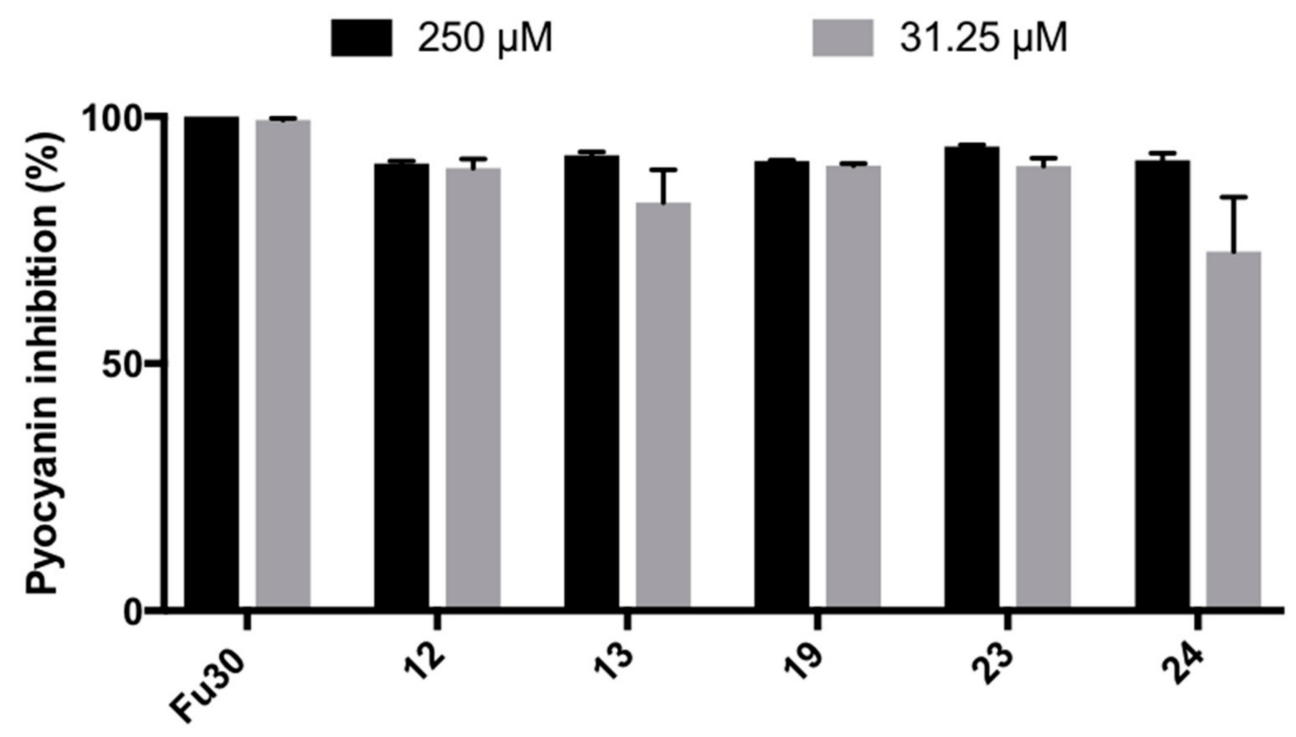

Figure 2. Pyocyanin inhibition in P. aeruginosa PAO1 by the synthesized compounds. Compounds were added to the bacteria at $250 \mu \mathrm{M}$ or $31.25 \mu \mathrm{M}$ and were incubated for $17 \mathrm{~h}$ with shaking. Pyocyanin production was measured at $695 \mathrm{~nm}$ in cell-free culture fluids. Error bars represent the standard error of two independent experiments.

The compounds were effective in inhibiting pyocyanin in the range of $90-94 \%$ at $250 \mu \mathrm{M}$. The compounds also showed potent activity at a lower concentration of $32 \mu \mathrm{M}(80-89 \%$ inhibition). Our QS-based inhibitors showed comparable pyocyanin inhibition activity to those reported by others [24]. The outcome of this assay correlates well with the potent QS activity of these compounds.

\subsection{Docking Studies}

Lactams 9-42 were docked into the binding site of an X-ray crystal structure of the LasR receptor protein (supplementary materials Table S2) in complex with OdDHL (PDB Code 2UV0) using the Genetic Optimisation for Ligand Docking (GOLD) algorithm through the Accelrys Discovery Studio software package. Before docking, the compounds were minimized using a CHARMM force field. The crystal structure consisted of four subunits (two sets of dimers); however, compounds were only docked into the binding site of subunit E following the results of previous control dockings. 
The co-crystallised OdDHL ligand (3) was docked back into the protein giving an acceptable root mean square of deviation (RMSD) of $0.94 \AA$ (heavy atoms) with the X-ray crystal structure.

The ligand-LasR interactions of Compounds 9-42 were analysed based on the highest scoring docked pose of the largest cluster. The predicted binding poses of Compounds 10, 11, 13, 15, 22, 26, and 31-42 were observed to be very similar to OdDHL, with the lactam carbonyl group of most compounds forming a hydrogen bond with Trp60 from the same position as the lactone ring of the natural ligand (Figure 3A,B). Interestingly, the remaining compounds were predicted to bind in a different pose, with the molecule flipped (Figure 3C). This alternate pose still allowed the carbonyl group of the lactam ring to form a hydrogen bond with Trp60, as was predicted for Compounds 9, 12, 14 and 25; however, it also allowed the lactam CO to form a hydrogen bond with Arg61, which was observed for the remaining compounds.

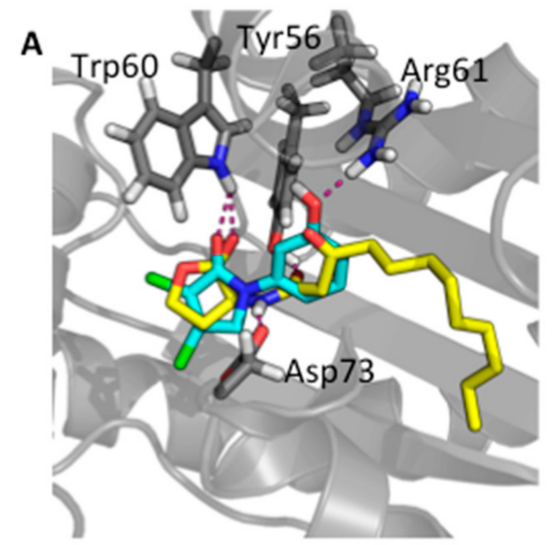

C

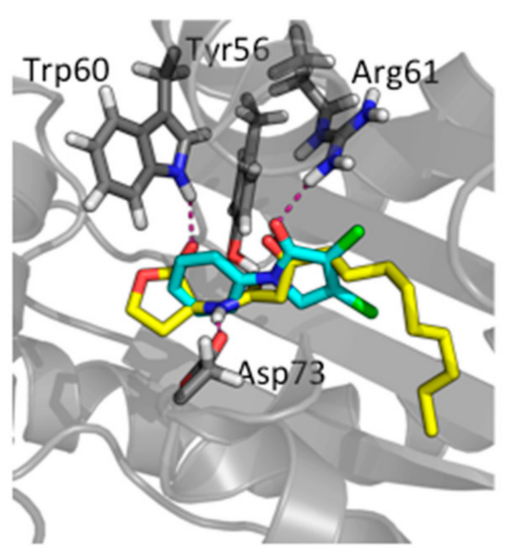

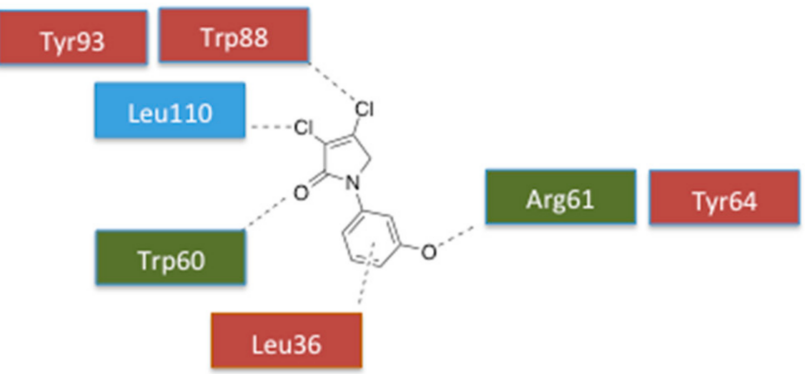

D

\section{\begin{tabular}{l|l} 
Leu36 Ala127 & \\
\hline
\end{tabular}}

Tyr64

\section{Arg61}

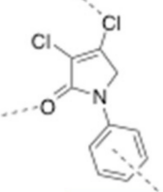

Tyr56 Asp73

Figure 3. Predicted interactions for ligands $\mathbf{1 3}$ and $\mathbf{2 3}$ in the binding pocket of LasR compared to N-(3-oxododecanoyl)-L-homoserine lactone 3 (OdDHL) (3). (A) Compound 13 shows OdDHL-like interactions and orientation. Hydrogen bonds are in pink. OdDHL is in yellow. (C) Compound 23 shows a flipped orientation relative to the lactone ring of OdDHL. (B,D) describe the interactions of 13 and 23 with LasR. Hydrogen bonds are green. Halogen interactions are blue. Hydrophobic and electrostatic interactions are red.

It was further observed that most of the compounds with high QSI were predicted to bind in a pose different from OdDHL. One explanation for this may be similar to that proposed by Bottomley et al., in that this pose severely limits the interaction with the hydrophobic pocket of the receptor and thus inhibits the formation of a stable protein conformation [26]. Previous studies by Gerdt et al. and Bottomley et al. have identified that hydrogen bonds to residues Ser129 and Thr115 are important for agonistic activity of ligands [26,27]. Notably, none of the QS inhibitors in this study were observed to form these hydrogen bonds, which is consistent with the antagonistic activity seen for 
these compounds. The predicted binding poses for Compounds 12 and $\mathbf{1 4}$ both shared the lactam ring in the same position, resulting in the main difference between the two being the interactions of the hydroxyl group of each compound. In Compound 12, the ortho hydroxyl group was predicted to form a hydrogen bond to Tyr56, whilst in the less active Compound 14, the para hydroxyl group formed a hydrogen bond with Tyr93. Hydrogen bonding to Tyr56 has been identified to be a key interaction in determining the agonistic or antagonistic behaviour of a compound, which may explain the much greater QSI activity observed for 12 [27].

The potent QS inhibitors 19, 23 and 24 form the same hydrogen bond with Arg61 and have a flipped orientation relative to the lactone head, but they form different interactions between the phenyl and the LasR binding pocket. The 4-aminophenyl group in Compound $\mathbf{1 9}$ forms an electrostatic $\pi$-anion with Asp73. This suggested that $\mathrm{NH}_{2}$ is not required for activity since Compounds 23 and 24 lack the amino group and yet have potent QS inhibition. Although there are no significant differences in QS activity between $\mathbf{2 3}$ and 24, the phenyl groups differ in the type of interactions they produce. Compound $\mathbf{2 3}$ makes hydrophobic interactions as shown in Figure 3C,D, while Compound 24 only forms an electrostatic $\pi$-anion interaction with Asp73. For the majority of docked compounds, the halogen at the 3-position of the lactam ring was not predicted to make any interactions with the LasR pocket except halogen interaction with Leu110 for Compound $\mathbf{1 3}$ and the least active compounds including 15, 33, 35-38 and 40-41. In contrast, the halogen at the 4-position was predicted to form hydrophobic interactions with the pocket for every docked compound including the most active ones. To further investigate the importance of these observations, a new series of compounds similar to those detailed in this study should be synthesized that lack a halogen at the 3-position of the lactam ring and have various hydrophobic alkyl or aromatic groups at the 4-position. Detailed docking results are provided in the Supplementary Information.

\section{Conclusions}

A small library of 34 lactam compounds was synthesized and evaluated for QS inhibition against P. aeruginosa. Compounds 9-42 were prepared in moderate to high yields via the reductive amination of mucochloric and mucobromic acid with a wide range of amines, including aliphatic, aromatic and heteroaromatic amines. In biological testing, several compounds possessed promising activities, with $12,13,23$ and 24 being the most active and showing comparable or even superior activity to the positive controls TP-5 and Fu-30 (5). The tested compounds showed low bacterial growth inhibition in contrast to Fu-30. Amides were also introduced to Compounds 16 and 20 to give the C-linked amides 32-38 and the $N$-linked amides 39-42, respectively. Generally, the amides 32-42 were less active compared to lactams 9-31, although the C-linked amides 32-38 were more potent than the $N$-linked amides 39-42. Several compounds showed high efficacy in pyocyanin inhibition, and the results are consistent with their potent QS activity. Docking of the synthesized compounds to the LasR receptor protein predicted favourable intermolecular interactions similar to OdDHL, including a hydrogen bond with the conserved polar Arg61 and Trp60 residues. The most active compounds were docked in a different orientation compared to OdDHL and did not form hydrogen bonds implicated in the stabilization of LasR by agonists. Overall, the results obtained from this study suggest that lactams derived from mucochloric and mucobromic acid could serve as new lead compounds for the development of potent QSI compounds that are unlikely to exert selective pressure on bacteria.

\section{Experimental}

\subsection{Chemistry}

Commercially-available reagents were purchased from Aldrich, Acros Organics, Alfa Aesar. The synthetic procedures have been reported for all compounds as general methods and appropriate references have been given for known compounds. Melting points were measured using a Mel-Temp melting point apparatus and were used uncorrected. High-resolution [+ESI] mass spectra were 
recorded by the Bioanalytical Mass Spectrometry Facility, UNSW, on an Orbitrap LTQ XL ion trap mass spectrometer using a nanospray (nano-electrospray) ionization source. ${ }^{1} \mathrm{H}$ and ${ }^{13} \mathrm{C}$ NMR spectra were determined in the designated solvent on a Bruker DPX 300 spectrometer or a Bruker Avance 400 spectrometer unless otherwise stated. Chemical shifts $(\delta)$ are quoted in parts per million (ppm), to the nearest $0.01 \mathrm{ppm}$ and internally referenced relative to the solvent nuclei. ${ }^{1} \mathrm{H}$ NMR spectral data are reported with their chemical shift in parts per million (ppm). The multiplicity in ${ }^{1} \mathrm{H}$ NMR is abbreviated as follows: brs, broad; s, singlet; d, doublet; $\mathrm{t}$, triplet; q, quartet; quint, quintet; sext, sextet; $\mathrm{m}$, multiplet; or as a combination (e.g., dd, dt, etc.). The coupling constant $(J)$ in hertz, integration and proton count were determined.

\subsection{General Procedure}

Procedure A: Reductive amination

Mucohalic acid (1 eq) was added to a solution of 5:3 $v / v$ dichloromethane/glacial acetic acid. Then, an amine (1 eq) was added, and the mixture was stirred for $10 \mathrm{~min}$. To that mixture, sodium triacetoxyborohydride ( 3 eq) solution in 5:3 $v / v$ dichloromethane and glacial acetic acid was added. The mixture was left to stir at room temperature for $24 \mathrm{~h}$ unless otherwise stated.

Procedure B: Amide coupling 1

Acid 16 (1 eq) was treated with thionyl chloride $(3 \mathrm{~mL})$ and refluxed for $3 \mathrm{~h}$ at $70{ }^{\circ} \mathrm{C}$. The mixture was then cooled and left to stir overnight at room temperature. Thionyl chloride was removed under high vacuum, and the resultant acid chloride was used without further purification. The acid chloride was dissolved in $10 \mathrm{~mL}$ of dry tetrahydrofuran, and triethylamine (1 eq) and amine (1 eq) were then added. The reaction mixture was left to stir at room temperature for $24 \mathrm{~h}$.

Procedure C: Amide coupling 2

The amine was dissolved in $10 \mathrm{~mL}$ of dry tetrahydrofuran, and then, triethylamine (1 eq) and acid chloride (1.0 eq) were added. The reaction mixture was left to stir at room temperature for $24 \mathrm{~h}$.

(1) 1-butyl-3,4-dichloro-1,5-dihydro-2H-pyrrol-2-one (9)

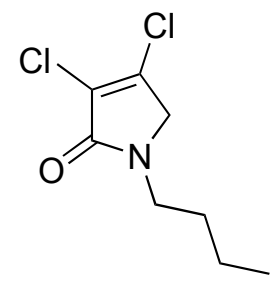

The title compound was prepared according to Procedure A from mucochloric acid (400 $\mathrm{mg}$, $2.3 \mathrm{mmol})$, butyl amine $(170 \mathrm{mg}, 270 \mathrm{~mL}, 2.3 \mathrm{mmol})$ and sodium triacetoxyborohydride $(1.46 \mathrm{~g}$, $6.9 \mathrm{mmol}$ ). The reaction mixture was left to react for $24 \mathrm{~h}$. The crude mixture was extracted with dichloromethane $(30 \mathrm{~mL})$ and washed with water $(15 \mathrm{~mL})$ followed by brine $(15 \mathrm{~mL})$, dried over sodium sulphate, and the solvent was evaporated. A residue of oil was obtained, which was purified by flash column chromatography using a gradient eluent of $25-50 \%$ ethyl acetate in hexane. A yellow oil was obtained $(390 \mathrm{mg} ; 79 \%) .{ }^{1} \mathrm{H}$ NMR $\left(\mathrm{CDCl}_{3}, 400 \mathrm{MHz}\right): \delta 0.95\left(\mathrm{t}, J=7.3,14.6 \mathrm{~Hz}, 3 \mathrm{H}, \mathrm{CH}_{3}\right)$, $\delta 1.36$ (sext, $J=7.2,15.0 \mathrm{~Hz}, 2 \mathrm{H}, \mathrm{CH}_{2}$ ), 1.58 (quint, $\left.J=7.2,15.0 \mathrm{~Hz}, 2 \mathrm{H}, \mathrm{CH}_{2}\right), \delta 3.50(\mathrm{t}, J=7.4,15.0$, $\left.2 \mathrm{H}, \mathrm{CH}_{2}\right), \delta 4.04\left(\mathrm{~s}, 2 \mathrm{H}, \mathrm{CH}_{2}\right) .{ }^{13} \mathrm{C} \mathrm{NMR}\left(\mathrm{CDCl}_{3}, 101\right): 13.7\left(\mathrm{CH}_{3}\right), 19.9\left(\mathrm{CH}_{2}\right), 30.4\left(\mathrm{CH}_{2}\right), 42.8\left(\mathrm{CH}_{2}\right)$, $53.4\left(\mathrm{C}_{-}-\mathrm{CH}_{2}\right), 125.9$ (C), 139.0 (C), 164.2 (C); IR (ATR): v $v_{\max }$ 2957.6, 2870.7, 1700.9, 1397.7, 1341.6, 1269.6, 1188.5, 1130.0, 843.9; UV (MeOH) $\lambda_{\max } 230.0 \mathrm{~nm}\left(\varepsilon 7488 \mathrm{~cm}^{-1} \mathrm{M}^{-1}\right) \mathrm{HRMS}$ (ESI) $\mathrm{m} / z$ calcd. for $\mathrm{C}_{8} \mathrm{H}_{11} \mathrm{Cl}_{2} \mathrm{~N}_{1} \mathrm{O}_{1} \mathrm{Na}_{1} 230.0110[\mathrm{M}+\mathrm{Na}]^{+}$, found 230.0108 .

(2) 3,4-dichloro-1-hexyl-1,5-dihydro-2H-pyrrol-2-one (10) 


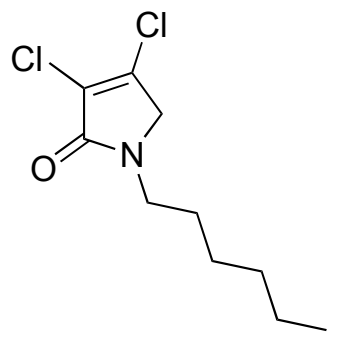

The title compound was prepared according to Procedure A from mucochloric acid (400 mg, $2.3 \mathrm{mmol})$, hexyl amine $(300 \mathrm{mg}, 270 \mathrm{~mL}, 2.3 \mathrm{mmol})$ and sodium triacetoxyborohydride $(1.46 \mathrm{~g}$, $6.9 \mathrm{mmol}$ ). The reaction mixture was left to react for $24 \mathrm{~h}$. The crude mixture was extracted with dichloromethane $(30 \mathrm{~mL})$ and washed with water $(15 \mathrm{~mL})$ followed by brine $(15 \mathrm{~mL})$, dried over sodium sulphate, and the solvent was evaporated and a residue oil obtained, which was purified by flash column chromatography using a gradient eluent of $25-50 \%$ ethyl acetate in hexane. A yellow oil was obtained $(220 \mathrm{mg} ; 39 \%) ;{ }^{1} \mathrm{H}$ NMR $\left(\mathrm{CDCl}_{3}, 400 \mathrm{MHz}\right): \delta 0.90\left(\mathrm{t}, J=6.9,13.5 \mathrm{~Hz}, 3 \mathrm{H}, \mathrm{CH}_{3}\right), \delta 1.24(\mathrm{~m}$, $\left.6 \mathrm{H}, \mathrm{CH}_{2}\right), \delta 1.60\left(\mathrm{~m}, 2 \mathrm{H}, \mathrm{CH}_{2}\right), \delta 3.49\left(\mathrm{t}, J=7.4,14.6 \mathrm{~Hz}, \mathrm{CH}_{2}\right), \delta 4.04\left(\mathrm{~s}, 2 \mathrm{H}, \mathrm{C} 5-\mathrm{CH}_{2}\right) .{ }^{13} \mathrm{C} \mathrm{NMR}\left(\mathrm{CDCl}_{3}\right.$ ， 101): $14.0\left(\mathrm{CH}_{3}\right), 22.5\left(\mathrm{CH}_{2}\right), 26.3\left(\mathrm{CH}_{2}\right), 28.3\left(\mathrm{CH}_{2}\right), 31.4\left(\mathrm{CH}_{2}\right), 43.1\left(\mathrm{CH}_{2}\right), 53.4\left(\mathrm{C}_{-}-\mathrm{CH}_{2}\right), 125.7(\mathrm{C})$, 139.2 (C), 164.2 (C=O); IR (ATR): $v_{\max } 2927.2,2857.2,1702.3,1438.2,1397.41367 .5,1131.0,1171.0,953.7$; $\mathrm{UV}(\mathrm{MeOH}) \lambda_{\max } 235.0 \mathrm{~nm}\left(\varepsilon 4248 \mathrm{~cm}^{-1} \mathrm{M}^{-1}\right)$; HRMS (ESI) $\mathrm{m} / z$ calcd. for $\mathrm{C}_{10} \mathrm{H}_{16} \mathrm{Cl}_{2} \mathrm{~N}_{1} \mathrm{O}_{1} 236.0603$ $[\mathrm{M}+\mathrm{H}]^{+}$, found 236.0601 .

(3) 1-benzyl-3,4-dichloro-1,5-dihydro-2H-pyrrol-2-one (11)<smiles>O=C1C(Cl)=C(Cl)CN1Cc1ccccc1</smiles>

The title compound was made according to Procedure A following the reported method [14]. m.p. $102.1{ }^{\circ} \mathrm{C} ;{ }^{1} \mathrm{H}$ NMR $\left(\mathrm{CDCl}_{3}, 400 \mathrm{MHz}\right): \delta 3.92\left(\mathrm{~s}, 2 \mathrm{H}, \mathrm{CH}_{2}\right), 4.67\left(\mathrm{~s}, 2 \mathrm{H}, \mathrm{CH}_{2}\right), 7.26-7.39(\mathrm{~m}, 5 \mathrm{H}, \mathrm{ArH})$; ${ }^{13} \mathrm{C} \mathrm{NMR}\left(\mathrm{CDCl}_{3}, 101\right): \delta 47.0\left(\mathrm{CH}_{2}\right), 52.8\left(\mathrm{CH}_{2}\right), 125.5(\mathrm{C}), 128.2(\mathrm{ArCH}), 129.0(\mathrm{ArCH}), 135.8,139.9$ (C), 164.28 (C=O); IR (ATR): $v_{\max } 2917.9,2850.9,1693.6,1437.5,1266.9,966.1,846.2,739.1$.

(4) 3,4-dichloro-1-(2-hydroxyphenyl)-1,5-dihydro-2H-pyrrol-2-one (12)<smiles>O=C1C(Cl)=C(Cl)CN1c1ccccc1O</smiles>

The title compound was prepared according to Procedure A from mucochloric acid (600 mg, 3.55 $\mathrm{mmol})$, ortho-aminophenol ( $388 \mathrm{mg}, 3.55 \mathrm{mmol}$ ) and sodium triacetoxyborohydride $(2.26 \mathrm{~g}, 10.65 \mathrm{mmol})$. The reaction mixture was left to react for $48 \mathrm{~h}$. The precipitated solid was filtered by vacuum filtration, and a white solid was obtained $(280 \mathrm{mg} ; 32 \%)$. m.p. $171.6{ }^{\circ} \mathrm{C} ;{ }^{1} \mathrm{H}$ NMR (DMSO- $d_{6}, 300 \mathrm{MHz}$ ): $\delta 4.61\left(\mathrm{~s}, 2 \mathrm{H}, \mathrm{CH}_{2}\right), \delta 6.85-6.97(\mathrm{~m}, 2 \mathrm{H}, \mathrm{ArH}), \delta 7.17-7.28(\mathrm{~m}, 2 \mathrm{H}, \mathrm{ArH}), 9.86(\mathrm{~s}, \mathrm{OH}) ;{ }^{13} \mathrm{C} \mathrm{NMR}$ (DMSO, 75.5 MHz): $55.4\left(\mathrm{CH}_{2}\right), 117.2(\mathrm{ArCH}), 119.6(\mathrm{ArCH}), 124.3(\mathrm{C}), 124.4(\mathrm{ArCH}), 129.3(\mathrm{ArCH})$, 
129.6 (ArCH), 142.0 (ArC), 153.5 (C), 163.1 (C=O); IR (ATR): $v_{\max }$ 3105.4, 1666.0, 1591.4, 1509.6, 1445.4, 1275.3, 1198.2, 930.5, 839.1; UV (MeOH): $\lambda_{\max } 280.0 \mathrm{~nm}\left(\varepsilon 2928 \mathrm{~cm}^{-1} \mathrm{M}^{-1}\right)$; HRMS (ESI) $m / z$ calcd. for $\mathrm{C}_{10} \mathrm{H}_{7} \mathrm{Cl}_{2} \mathrm{~N}_{1} \mathrm{O}_{2} \mathrm{Na}_{1} 265.9746[\mathrm{M}+\mathrm{Na}]^{+}$, found 265.9744 .

(5) 3,4-dichloro-1-(3-hydroxyphenyl)-1,5-dihydro-2H-pyrrol-2-one (13)<smiles>O=C1C(Cl)=C(Cl)CN1c1cccc(O)c1</smiles>

The title compound was prepared according to Procedure A following the reported method [14] from mucochloric acid (600 mg, $3.55 \mathrm{mmol})$, meta-aminophenol (388 $\mathrm{mg}, 3.55 \mathrm{mmol}$ ) and sodium triacetoxyborohydride $(2.26 \mathrm{~g}, 10.65 \mathrm{mmol})$. The reaction mixture was left to react for $24 \mathrm{~h}$. As the reaction progresses, a yellow precipitated solid was evident. The solid was filtered by vacuum filtration and a yellow solid was obtained (578 mg; 66\%); m.p. $163.6{ }^{\circ} \mathrm{C} ;{ }^{1} \mathrm{H}$ NMR (DMSO- $\left.d_{6}, 400 \mathrm{MHz}\right): \delta 4.80$ $\left(\mathrm{s}, 2 \mathrm{H}, \mathrm{CH}_{2}\right), \delta 6.59(\mathrm{~d}, J=8.0 \mathrm{~Hz}, 1 \mathrm{H}, \mathrm{ArH}), 7.04(\mathrm{~d}, J=9.3 \mathrm{~Hz}, 1 \mathrm{H}, \mathrm{ArH}), 7.18(\mathrm{t}, J=8.0 \mathrm{~Hz}, 1 \mathrm{H}$, $\mathrm{ArH}), 7.28$ (s, 1H, ArH), 9.71 (brs, OH); ${ }^{13} \mathrm{C} \mathrm{NMR}(\mathrm{DMSO}, 100 \mathrm{MHz}): 54.0\left(\mathrm{CH}_{2}\right), 106.6(\mathrm{ArCH}), 109.8$ $(\mathrm{ArCH}), 112.3(\mathrm{ArCH}), 124.3(\mathrm{C}), 130.2(\mathrm{ArCH}), 139.8(\mathrm{C}), 141.9(\mathrm{C}), 158.4(\mathrm{C}), 162.4(\mathrm{C}=\mathrm{O})$; UV (MeOH): $\lambda_{\max } 280.0 \mathrm{~nm}\left(\varepsilon 3854 \mathrm{~cm}^{-1} \mathrm{M}^{-1}\right)$; HRMS (ESI) $m / z$ calcd. for $\mathrm{C}_{10} \mathrm{H}_{7} \mathrm{Cl}_{2} \mathrm{~N}_{1} \mathrm{O}_{2} \mathrm{Na}_{1} 265.9746[\mathrm{M}+\mathrm{Na}]^{+}$, found 265.9745 .

(6) 3,4-dichloro-1-(4-hydroxyphenyl)-1,5-dihydro-2H-pyrrol-2-one (14)<smiles>O=C1C(Cl)=C(Cl)CN1c1ccc(O)cc1</smiles>

The title compound was prepared according to Procedure A from mucochloric acid (600 mg, $3.55 \mathrm{mmol}), 4$-aminophenol $(388 \mathrm{mg}, 3.55 \mathrm{mmol})$ and sodium triacetoxyborohydride (2.26 g, $10.65 \mathrm{mmol})$. The reaction mixture was left to react for $24 \mathrm{~h}$. As the reaction progressed, a yellow precipitated solid was evident. The solid was filtered by vacuum filtration, and a yellow solid was obtained (500 mg; 58\%); m.p. $126.0{ }^{\circ} \mathrm{C} ;{ }^{1} \mathrm{H} \mathrm{NMR}\left(\mathrm{DMSO}-d_{6}, 400 \mathrm{MHz}\right): \delta 4.77\left(\mathrm{~s}, 2 \mathrm{H}, \mathrm{CH}_{2}\right)$, $\delta 6.81(\mathrm{~d}, J=8.9 \mathrm{~Hz}, 2 \mathrm{H}, \mathrm{ArH}), \delta 7.44(\mathrm{~d}, J=8.9 \mathrm{~Hz}, 2 \mathrm{H}, \mathrm{ArH}), 9.8(\mathrm{brs}, 1 \mathrm{H}, \mathrm{OH}) ;{ }^{13} \mathrm{C}$ NMR (DMSO, $100 \mathrm{MHz}): 54.5\left(\mathrm{CH}_{2}\right), 115.8(\mathrm{ArCH}), 122.2(\mathrm{ArCH}), 124.3(\mathrm{C}), 130.3(\mathrm{ArC}), 141.2(\mathrm{ArC}), 155.4(\mathrm{C}), 162.1$ $(\mathrm{C}=\mathrm{O}), \mathrm{IR}(\mathrm{ATR}): v_{\max } 3277.8,1682.9,1630.2,1510.6,1270.8,1219.3,1046.9,934.0,830.7 ; \mathrm{UV}(\mathrm{MeOH})$ : $\lambda_{\max } 280.0 \mathrm{~nm}\left(\varepsilon 1090.2 \mathrm{~cm}^{-1} \mathrm{M}^{-1}\right)$; HRMS (ESI) $m / z$ calcd. for $\mathrm{C}_{10} \mathrm{H}_{7} \mathrm{Cl}_{2} \mathrm{~N}_{1} \mathrm{O}_{2} \mathrm{Na}_{1} 265.9746[\mathrm{M}+\mathrm{Na}]^{+}$, found 265.9745 .

(7) N-(3-carboxyphenyl)-3,4-dibromo-1,5-dihydro-2H-pyrrol-2-one (DHP phenyl acid-2) (15) 


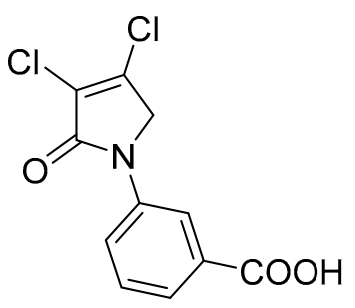

The title compound was synthesized according to Procedure A from mucochloric acid ( $1 \mathrm{~g}$, $5.91 \mathrm{mmol}), 3$-aminobenzoic acid $(0.81 \mathrm{~g}, 5.91 \mathrm{mmol})$ and sodium triacetoxyborohydride $(3.76 \mathrm{~g}$, $17.75 \mathrm{mmol})$ in $5: 3 \mathrm{v} / \mathrm{v}$ dichloromethane/glacial acetic acid $(12 \mathrm{~mL})$. The reaction mixture was left to stir at room temperature for $18 \mathrm{~h}$, during which time, a yellow precipitate was evident. The mixture was filtered under vacuum, and the filtered solid was purified by flash chromatography. The solid was then recrystallized in methanol after chromatography to yield the pure title product as a white solid (0.54g; 34\%); m.p. $214-216{ }^{\circ} \mathrm{C} ;{ }^{1} \mathrm{H}$ NMR (300 MHz, DMSO-d $\left.d_{6}\right) \delta 4.93\left(\mathrm{~s}, 2 \mathrm{H}, \mathrm{CH}_{2}\right), \delta 7.55$ (t, $J=7.98 \mathrm{~Hz}$, $1 \mathrm{H}, \mathrm{ArH}), \delta 7.74(\mathrm{tt}, J=7.98$ and $1.48 \mathrm{~Hz}, 1 \mathrm{H}, \mathrm{ArH}), \delta 7.89-7.93(\mathrm{~m}, 1 \mathrm{H}, \mathrm{ArH}), \delta 8.34(\mathrm{t}, J=1.8 \mathrm{~Hz}, 1 \mathrm{H}$, ArH), $\delta 13.13$ (brs, $1 \mathrm{H}, \mathrm{COOH}) ;{ }^{13} \mathrm{C}$ NMR $\left(75.5 \mathrm{MHz}, \mathrm{DMSO}-d_{6}\right) \delta 54.0\left(\mathrm{CH}_{2}\right), 120.0(\mathrm{ArCH}), 123.4$ $(\mathrm{ArCN}), 125.8(\mathrm{ArC}), 129.9(\mathrm{ArCH}), 132.1(\mathrm{ArCH}), 138.9(\mathrm{ArCH}), 142.4(2 \times \mathrm{CCl}), 162.7(\mathrm{C}=\mathrm{O}), 167.3$ (C=O); IR (ATR): $v_{\max } 2969,2824,2654,2539,1699,1586,1491,1433,1382,1313,1272,1158,1051,938$, 899, 818, 757, 739, $677 \mathrm{~cm}^{-1}$; UV (THF): $\lambda_{\max } 236 \mathrm{~nm}\left(\varepsilon 20671 \mathrm{~cm}^{-1} \mathrm{M}^{-1}\right), 288$ (32,346); HRMS (ESI) $m / z$ calcd. for $\mathrm{C}_{11} \mathrm{H}_{7} \mathrm{Cl}_{2} \mathrm{NO}_{3} \mathrm{Na} 293.9695[\mathrm{M}+\mathrm{Na}]^{+}$, found 293.9698 .

(8) $\mathrm{N}$-(4-carboxyphenyl)-3,4-dichloro-1,5-dihydro-2H-pyrrol-2-one (16)<smiles>O=C(O)c1ccc(N2CC(Cl)=C(Cl)C2=O)cc1</smiles>

The title compound was synthesized according to Procedure A, by first dissolving mucochloric acid $(1 \mathrm{~g}, 5.91 \mathrm{mmol})$ in $5: 3 v / v$ dichloromethane/glacial acetic acid $(12 \mathrm{~mL})$. To this mixture, a solution of $p$-aminobenzoic acid $(0.81 \mathrm{~g}, 5.91 \mathrm{mmol})$ in dichloromethane $(8 \mathrm{~mL})$ was added followed by sodium triacetoxyborohydride $(3.76 \mathrm{~g}, 17.75 \mathrm{mmol})$. The reaction mixture was stirred at room temperature for $18 \mathrm{~h}$, during which time a yellow precipitate was evident. The mixture was filtered under vacuum and washed with dichloromethane and distilled water to yield a yellow solid $(0.6 \mathrm{~g} ; 37 \%)$. m.p. $229{ }^{\circ} \mathrm{C} ;{ }^{1} \mathrm{H}$ NMR (300 MHz, DMSO- $\left.d_{6}\right) \delta 4.91\left(\mathrm{~s}, 2 \mathrm{H}, \mathrm{CH}_{2}\right), \delta$ 7.84-7.88 (m, 2H, ArH), $\delta$ 7.96-8.01 (m, 2H, ArH), $\delta 12.8$ (brs, $1 \mathrm{H}, \mathrm{COOH}) ;{ }^{13} \mathrm{C} \mathrm{NMR}\left(75.5 \mathrm{MHz}, \mathrm{DMSO}-d_{6}\right) \delta 53.9\left(\mathrm{CH}_{2}\right), 118.3(2 \times \mathrm{ArCH}), 124.2(\mathrm{ArCN})$, $126.7(\mathrm{ArC}), 130.9(2 \times \mathrm{ArCH}), 142.4(\mathrm{CCl}), 142.8(\mathrm{CCl}), 162.8(\mathrm{C}=\mathrm{O}), 167.1(\mathrm{C}=\mathrm{O})$; IR $(\mathrm{ATR}): v_{\max } 2939$, 2814, 2659, 2537, 1679, 1604, 1516, 1425, 1375, 1279, 1042, 934, 860, 769, 741, $718 \mathrm{~cm}^{-1}$; UV (THF): $\lambda_{\max }$ $236 \mathrm{~nm}\left(\varepsilon 5338 \mathrm{~cm}^{-1} \mathrm{M}^{-1}\right), 289$ (2736); HRMS (ESI) $m / z$ calcd. for $\mathrm{C}_{11} \mathrm{H}_{7} \mathrm{Cl}_{2} \mathrm{NO}_{3} \mathrm{Na} 293.9695[\mathrm{M}+\mathrm{Na}]^{+}$, found 293.9696.

(9) N-(3-tert-butylphenylcarbamate)-3,4-dichloro-1,5-dihydro-2H-pyrrol-2-one (17) 


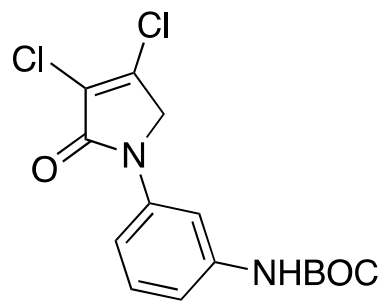

The title compound was prepared from mucochloric acid $(1.0 \mathrm{~g}, 5.91 \mathrm{mmol})$, $\mathrm{N}$-Boc-m-phenylenediamine $(1.2 \mathrm{~g}, 5.91 \mathrm{mmol})$ and sodium triacetoxyborohydride $(3.7 \mathrm{~g}, 17.75 \mathrm{mmol})$ in 5:3 $v / v$ dichloromethane/glacial acetic acid $(12 \mathrm{~mL})$. The mixture was stirred at room temperature for $3.5 \mathrm{~h}$. The reaction mixture was washed with water and brine and then extracted into ethyl acetate. The organic layer was dried over sodium sulphate and evaporated in vacuo. The solid was recrystallized in DCM and hexane to yield the title compound as a yellow solid (1.36 g, 67.17\%). m.p. 131-132 ${ }^{\circ} \mathrm{C} ;{ }^{1} \mathrm{H}$ NMR $(300 \mathrm{MHz}$, DMSO-d 6$) \delta 1.48\left(\mathrm{~s}, 9 \mathrm{H}, 3 \times \mathrm{CH}_{3}\right), \delta 4.80\left(\mathrm{~s}, 2 \mathrm{H}, \mathrm{CH}_{2}\right), \delta 7.29(\mathrm{~m}, 3 \mathrm{H}$, $\mathrm{ArH}), 7.97(\mathrm{~s}, 1 \mathrm{H}, \mathrm{ArH}), \delta 9.45(\mathrm{~s}, 1 \mathrm{H}, \mathrm{NH}) ;{ }^{13} \mathrm{C} \mathrm{NMR}\left(100 \mathrm{MHz}, \mathrm{DMSO}-d_{6}\right) \delta 28.6\left(3 \times \mathrm{CH}_{3}\right), \delta 54.1$ $\left(\mathrm{CH}_{2}\right), \delta$ 79.6.0 (C-O), $113.2(\mathrm{ArC}), 115.1(\mathrm{ArC}), 124.2$ @ , $129.6(\mathrm{ArCH}), 139.0(\mathrm{ArCH}), 140.7(\mathrm{ArC}), 153.2$ $(\mathrm{C}=\mathrm{O}), 162.4(\mathrm{C}=\mathrm{O})$; IR (ATR): $v_{\max } 3305,2977,1695,1604,1498,1421,1388,1285,1227,1151,945,876$, $683, \mathrm{~cm}^{-1}$; HRMS (ESI) $\mathrm{m} / z$ calcd. for $\mathrm{C}_{15} \mathrm{H}_{16} \mathrm{Cl}_{2} \mathrm{~N}_{2} \mathrm{O}_{3} \mathrm{Na} 365.0430[\mathrm{M}+\mathrm{Na}]^{+}$, found 381.0428.

(10) $\mathrm{N}$-(4'-tert-butylphenylcarbamate)-3,4-dichloro-1,5-dihydro-2H-pyrrol-2-one (18)<smiles>CC(C)(C)OCc1ccc(N2CC(Cl)=C(Cl)C2=O)cc1</smiles>

The title compound was prepared according to Procedure A from mucochloric acid $(0.9 \mathrm{~g}$, $5.36 \mathrm{mmol}), N$-Boc- $p$-phenylenediamine $(1.1 \mathrm{~g}, 5.36 \mathrm{mmol})$ and sodium triacetoxyborohydride $(3.38 \mathrm{~g}$, $15.98 \mathrm{mmol})$ in 5:3 $v / v$ dichloromethane/glacial acetic acid $(12 \mathrm{~mL})$. The mixture was stirred at room temperature for $3 \mathrm{~h}$. The reaction mixture was washed with water and brine and then extracted into ethyl acetate. The organic layer was dried over sodium sulphate and evaporated in vacuo to yield the title compound as a dark red solid $(1.16 \mathrm{~g}, 64 \%)$. m.p. $130-131{ }^{\circ} \mathrm{C} ;{ }^{1} \mathrm{H}$ NMR $\left(400 \mathrm{MHz}\right.$, DMSO- $\left.d_{6}\right) \delta$ $1.48\left(\mathrm{~s}, 9 \mathrm{H}, 3 \times \mathrm{CH}_{3}\right), \delta 4.8\left(\mathrm{~s}, 2 \mathrm{H}, \mathrm{CH}_{2}\right), \delta 7.46(\mathrm{dd}, J=41.9$ and $9 \mathrm{~Hz}, 4 \mathrm{H}, \mathrm{ArH}), \delta 9.38(\mathrm{~s}, 1 \mathrm{H}, \mathrm{NH})$; ${ }^{13} \mathrm{C}$ NMR $\left(100 \mathrm{MHz}\right.$, DMSO- $\left.d_{6}\right) \delta 28.5\left(3 \times \mathrm{CH}_{3}\right), \delta 54.1\left(\mathrm{CH}_{2}\right), \delta 82.0(\mathrm{C}-\mathrm{O}), \delta 118.9(2 \times \mathrm{ArCH}), 120.3$ (ArC), $124.2(\mathrm{ArC}), 133.1(2 \times \mathrm{ArCH}), 136.9(\mathrm{CCl}), 141.5(\mathrm{CCl}), 153.2(\mathrm{C}=\mathrm{O}), 162.2(\mathrm{C}=\mathrm{O})$; IR (ATR): $v_{\max } 3345,2923,2321,1698,1589,1519,1385,1312,1228,1151,1025,932,831,758 \mathrm{~cm}^{-1}$; UV (ACN): $\lambda_{\max } 245 \mathrm{~nm}\left(\varepsilon \mathrm{c} 3,990 \mathrm{~cm}^{-1} \mathrm{M}^{-1}\right)$; HRMS (ESI) $\mathrm{m} / z$ calcd. for $\mathrm{C}_{15} \mathrm{H}_{16} \mathrm{Cl}_{2} \mathrm{~N}_{2} \mathrm{O}_{3} \mathrm{Na} 365.0430[\mathrm{M}+\mathrm{Na}]^{+}$, found 381.0426 .

(11) N-(3-aminophenyl)-3,4-dichloro-1,5-dihydro-2H-pyrrol-2-one (19)<smiles>Nc1cccc(N2CC(Cl)=C(Cl)C2=O)c1</smiles> 
The title compound was prepared according to Procedure A using Compound 17. The Boc group was cleaved by treating $17(1.36 \mathrm{~g})$ with trifluoroacetic acid $(6 \mathrm{~mL})$ at room temperature for $1 \mathrm{~h}$ followed by evaporation of TFA under high vacuum. The residue was neutralized and washed with saturated solution of sodium bicarbonate, and the solid obtained was filtered under vacuum to yield a red solid (0.75 g, 78\%). m.p. $109{ }^{\circ} \mathrm{C} ;{ }^{1} \mathrm{H}$ NMR (300 MHz, DMSO-d 6$) \delta 4.75$ (s, 2H, CH $), 5.21$ (brs, 2H, NH $)$, $\delta 6.43(\mathrm{dd}, J=6.42,7.7 \mathrm{~Hz}, 1 \mathrm{H}, \mathrm{ArH}), 6.78(\mathrm{dd}, J=6.4,7.7 \mathrm{~Hz}, 1 \mathrm{H}, \mathrm{ArH}), 7.04-7.12(\mathrm{~m}, 2 \mathrm{H}, \mathrm{ArH})$; ${ }^{13} \mathrm{C}$ NMR $\left(75.5 \mathrm{MHz}, \mathrm{DMSO}-d_{6}\right) \delta 54.0\left(\mathrm{CH}_{2}\right), \delta 105.4(\mathrm{ArCH}), 107.3(\mathrm{ArCH}), 111.4(\mathrm{ArCH}), 124.3(\mathrm{C})$, 129.8 (ArCH), 139.4 (ArC), 141.6 (ArC), 149.0 (C), 162.2 (C=O); IR (ATR): $v_{\max } 3340,1687,1466,1389$, $1268,949,758$, HRMS (ESI) $m / z$ calcd. for $\mathrm{C}_{10} \mathrm{H}_{8} \mathrm{Cl}_{2} \mathrm{~N}_{2} \mathrm{O}^{1} 243.0086[\mathrm{M}+1]^{+}$, found 243.0084.

(12) N-(4-aminophenyl)-3,4-dichloro-1,5-dihydro-2H-pyrrol-2-one (20)<smiles>Nc1ccc(N2CC(Cl)=C(Cl)C2=O)cc1</smiles>

The title compound was prepared according to Procedure A from the Boc group, which was cleaved by treating intermediate $18(0.53 \mathrm{~g})$ with trifluoroacetic acid $(5 \mathrm{~mL})$ at room temperature for 1 $\mathrm{h}$ followed by evaporation of TFA under high vacuum. The residue was neutralized and washed with saturated solution of sodium bicarbonate, and the solid obtained was filtered under vacuum to yield a red solid (0.25 g, 64\%). m.p. $106{ }^{\circ} \mathrm{C} ;{ }^{1} \mathrm{H}$ NMR (300 MHz, DMSO-d 6$) \delta 4.7\left(\mathrm{~s}, 2 \mathrm{H}, \mathrm{CH}_{2}\right), \delta 5.13$ (brs, $\left.1 \mathrm{H}, \mathrm{NH}_{2}\right), \delta 6.55-6.6(\mathrm{~m}, 2 \mathrm{H}, \mathrm{ArH}), \delta 7.24-7.29(\mathrm{~m}, 2 \mathrm{H}, \mathrm{ArH}) ;{ }^{13} \mathrm{C}$ NMR $\left(75.5 \mathrm{MHz}, \mathrm{DMSO}-d_{6}\right) \delta 54.6$ $\left(\mathrm{CH}_{2}\right), \delta 114.2(2 \times \mathrm{ArCH}), 121.5(\mathrm{ArC}), 122.3(2 \times \mathrm{ArCH}), 127.5(\mathrm{ArC}), 140.6(\mathrm{CCl}), 146.9(\mathrm{CCl}), 163.0$ $(\mathrm{C}=\mathrm{O})$; IR (ATR): $v_{\max } 3297,3205,2921,1697,1636,1515,1400,1389,1300,1175,1043,928,812 \mathrm{~cm}^{-1}$; $\mathrm{UV}(\mathrm{ACN}): \lambda_{\max } 247 \mathrm{~nm}\left(\varepsilon 10,817 \mathrm{~cm}^{-1} \mathrm{M}^{-1}\right.$ ), 307 (5783); HRMS (ESI) $m / z$ calcd. for $\mathrm{C}_{10} \mathrm{H}_{8} \mathrm{Cl}_{2} \mathrm{~N}_{2} \mathrm{ONa}$ $264.9906[\mathrm{M}+\mathrm{Na}]^{+}$, found 264.9909 .

(13) 4-(3,4-dichloro-2-oxo-2,5-dihydro-1H-pyrrol-1-yl)butanoic acid (21)<smiles>O=C(O)CCCN1CC(Cl)=C(Cl)C1=O</smiles>

The title compound was synthesized according to Procedure A, by first dissolving mucochloric acid $(1.0 \mathrm{~g}, 5.9 \mathrm{mmol})$ in 5:3 $\mathrm{v} / \mathrm{v}$ dichloromethane/glacial acetic acid (12 $\mathrm{mL})$. To this mixture, a solution of aminobutanoic acid $(0.61 \mathrm{~g}, 5.9 \mathrm{mmol})$ in dichloromethane $(8 \mathrm{~mL})$ was added followed by sodium triacetoxyborohydride $(3.76 \mathrm{~g}, 17.75 \mathrm{mmol})$ to yield a white solid $(0.41 \mathrm{~g}, 30 \%)$. m.p. $106{ }^{\circ} \mathrm{C} ;{ }^{1} \mathrm{H}$ NMR (300 MHz, DMSO-d 6 ) $\delta 1.91\left(\mathrm{~m}, \mathrm{CH}_{2}\right), \delta 2.42\left(\mathrm{~m}, \mathrm{CH}_{2}\right), \delta 3.56(\mathrm{t}, J=7.0 \mathrm{~Hz}), \delta 4.07\left(\mathrm{~s}, \mathrm{C}^{-} \mathrm{CH}_{2}\right)$; ${ }^{13} \mathrm{C}$ NMR $\left(75.5 \mathrm{MHz}, \mathrm{DMSO}-d_{6}\right) \delta 23.42\left(\mathrm{CH}_{2}\right), 30.82\left(\mathrm{CH}_{2}\right), 42.40\left(\mathrm{CH}_{2}\right), 53.56\left(\mathrm{C} 5-\mathrm{CH}_{2}\right), 125.7(\mathrm{C})$, 139.7 (C), 164.7 (C=O), 176.9 (C=O); IR (ATR): $v_{\max } 3936,2641,1735,1339,1289,1195,859,745 \mathrm{~cm}^{-1}$; HRMS (ESI) $m / z$ calcd. for $\mathrm{C}_{8} \mathrm{H}_{9} \mathrm{Cl}_{2} \mathrm{~N}_{1} \mathrm{O}_{3} \mathrm{Na}_{1} 259.9852[\mathrm{M}+\mathrm{Na}]^{+}$, found 259.9850 .

(14) 1-allyl-3,4-dichloro-1,5-dihydro-2H-pyrrol-2-one (22) 
<smiles>C=CCN1CC(Cl)=C(Cl)C1=O</smiles>

The title compound was prepared according to Procedure A from mucochloric acid (600 $\mathrm{mg}$, $3.55 \mathrm{mmol})$, allylamine $(202.7 \mathrm{mg}, 3.55 \mathrm{mmol})$ and sodium triacetoxyborohydride $(2.26 \mathrm{~g}, 10.65 \mathrm{mmol})$. The reaction mixture was left to react for 3 days. The crude mixture was extracted with dichloromethane $(30 \mathrm{~mL})$ and washed with water $(15 \mathrm{~mL})$ followed by brine $(15 \mathrm{~mL})$, dried over sodium sulphate, and the solvent was evaporated and a residue oil obtained, which was purified by flash column chromatography using a gradient eluent of $5 \%$ to $25 \%$ ethyl acetate and hexane. A yellow oil was obtained (244 mg, 36\%); ${ }^{1} \mathrm{H} \mathrm{NMR}\left(\mathrm{CDCl}_{3}, 300 \mathrm{MHz}\right): 4.01\left(\mathrm{~s}, 2 \mathrm{H}, \mathrm{C} 5-\mathrm{CH}_{2}\right), 4.11(\mathrm{~d}, J=6.1 \mathrm{~Hz}, 2 \mathrm{H}$, $\left.\mathrm{N}-\mathrm{CH}_{2}\right), 5.20-5.80\left(\mathrm{~m}, 2 \mathrm{H}, \mathrm{HC}=\mathrm{CH}_{2}\right), 5.74-5.80\left(\mathrm{~m}, 1 \mathrm{H}, \underline{\mathrm{HC}}=\mathrm{CH}_{2}\right) ;{ }^{13} \mathrm{C} \mathrm{NMR}\left(\mathrm{CDCl}_{3}, 75.5 \mathrm{MHz}\right)$ : $45.5\left(\mathrm{CH}_{2}\right), 52.9\left(\mathrm{C}_{-}-\mathrm{CH}_{2}\right), 119.0\left(\mathrm{HC}=\mathrm{CH}_{2}\right), 125.6(\mathrm{CCl}), 132.0\left(\mathrm{HC}=\mathrm{CH}_{2}\right), 139.8$ (C) 164.0 (C); IR (ATR): $v_{\max } 3290.1,1685.5,1621.0,1402.1,1270.5,1157.0,1100.6,929.8,841.8 ; \mathrm{UV}(\mathrm{MeOH}): \lambda_{\max } 280.0 \mathrm{~nm}$ $\left(\varepsilon 4928 \mathrm{~cm}^{-1} \mathrm{M}^{-1}\right)$; HRMS (ESI) $\mathrm{m} / z$ calcd. for $\mathrm{C}_{7} \mathrm{H}_{7} \mathrm{Cl}_{2} \mathrm{~N}_{1} \mathrm{O}_{1} \mathrm{Na}_{1} 213.9797[\mathrm{M}+\mathrm{Na}]^{+}$, found 213.9794 .

(15) 3,4-dichloro-1-phenyl-1,5-dihydro-2H-pyrrol-2-one (23)<smiles>O=C1C(Cl)=C(Cl)CN1c1ccccc1</smiles>

The title compound was prepared according to Procedure A from mucochloric acid $(1 \mathrm{~g}$, $5.92 \mathrm{mmol})$, aniline $(551.2 \mathrm{mg}, 5.92 \mathrm{mmol})$ and sodium triacetoxyborohydride $(3.76 \mathrm{~g}, 17.76 \mathrm{mmol})$. The reaction mixture was left to react for $48 \mathrm{~h}$. The reaction mixture was extracted with dichloromethane $(30 \mathrm{~mL})$ and washed with water $(15 \mathrm{~mL})$ followed by brine $(15 \mathrm{~mL})$, dried over sodium sulphate, and the solvent was evaporated. The obtained semi solid was triturated with methanol, and the precipitated solid was collected by vacuum filtration and dried over silica in the desiccator. A white small needle solid was obtained $(680 \mathrm{mg}, 99 \%)$. m.p. $201.2{ }^{\circ} \mathrm{C} ;{ }^{1} \mathrm{H}$ NMR (DMSO- $\left.d_{6}, 300 \mathrm{MHz}\right): \delta 4.86\left(\mathrm{~s}, 2 \mathrm{H}, \mathrm{CH}_{2}\right)$, $7.20(\mathrm{t}, J=9.0 \mathrm{~Hz}, 1 \mathrm{H}, \mathrm{ArH}), 7.43(\mathrm{t}, J=9.00 \mathrm{~Hz}, 2 \mathrm{H}, \mathrm{ArH}), 7.73(\mathrm{~d}, J=9.0 \mathrm{~Hz}, 2 \mathrm{H}, \mathrm{ArH}) ;{ }^{13} \mathrm{C} \mathrm{NMR}$ (DMSO, 75.5MHz): $\left.54.0\left(\mathrm{CH}_{2}\right), 119.5(\mathrm{ArCH}), 124.3(\mathrm{C}), 125.1(\mathrm{ArC})\right), 129.6(\mathrm{ArCH}), 139.0(\mathrm{C}), 142.0(\mathrm{C})$, 162.5 (C=O); IR (ATR): $v_{\max } 3060.4,2918.3,1688.4,1628.9,1500.0,1437.1,1298.7,1153.3,1049.2,927.4$, 755.6; UV (MeOH): $\lambda_{\max } 280.0 \mathrm{~nm}\left(\varepsilon 3854.4 \mathrm{~cm}^{-1} \mathrm{M}^{-1}\right.$ ); HRMS (ESI) $m / z$ calcd. for $\mathrm{C}_{10} \mathrm{H}_{7} \mathrm{Cl}_{2} \mathrm{~N}_{1} \mathrm{O}_{1} \mathrm{Na}_{1}$ $249.9797[\mathrm{M}+\mathrm{Na}]^{+}$, found 249.9794 .

(16) 3,4-dibromo-1-phenyl-1,5-dihydro-2H-pyrrol-2-one (24)<smiles>O=C1C(Br)=C(Br)CN1c1ccccc1</smiles>

The title compound was prepared according to Procedure A from mucobromic acid $(1.20 \mathrm{~g}$, $4.65 \mathrm{mmol})$, aniline $(433.3 \mathrm{mg}, 4.65 \mathrm{mmol})$ and sodium triacetoxyborohydride ( $3.60 \mathrm{~g}, 13.95 \mathrm{mmol})$. 
The reaction mixture was left to stir for $48 \mathrm{~h}$. The precipitated solid was filtered by vacuum filtration, and a white solid was obtained $(440 \mathrm{mg} ; 30 \%)$; m.p. $160.7{ }^{\circ} \mathrm{C} ;{ }^{1} \mathrm{H}$ NMR (DMSO- $\left.d_{6}, 300 \mathrm{MHz}\right): \delta 4.88$ (s, 2H, $\left.\mathrm{CH}_{2}\right), 7.18(\mathrm{t}, J=7.5 \mathrm{~Hz}, 1 \mathrm{H}, \mathrm{ArH}), 7.43(\mathrm{t}, J=7.5 \mathrm{~Hz}, 2 \mathrm{H}, \mathrm{ArH}), 7.72(\mathrm{~d}, J=8.7 \mathrm{~Hz}, 1 \mathrm{H}, \mathrm{ArH})$; ${ }^{13} \mathrm{C}$ NMR (DMSO, 75.5 MHz): $57.3\left(\mathrm{CH}_{2}\right), 119.4(\mathrm{ArCH}), 119.8(\mathrm{ArC}), 125.0(\mathrm{C}), 129.5(\mathrm{ArCH}), 136.4(\mathrm{C})$, 138.8 (C), 163.3 (C); IR (ATR): $v_{\max } 3059.5,1692.5,1589.5,1421.5,1374.4,1145.1,1035.1,885.4,753.7 ; \mathrm{UV}$ $(\mathrm{MeOH}): \lambda_{\max } 280.0 \mathrm{~nm}\left(\varepsilon 7829 \mathrm{~cm}^{-1} \mathrm{M}^{-1}\right)$; HRMS (ESI) $m / z$ calcd. for $\mathrm{C}_{10} \mathrm{H}_{7} \mathrm{Br}_{2} \mathrm{~N}_{1} \mathrm{O}_{1} \mathrm{Na}_{1} 337.8787$ $[\mathrm{M}+\mathrm{Na}]^{+}$, found 337.8789 .

(17) 3,4-dibromo-1-(3-hydroxyphenyl)-1,5-dihydro-2H-pyrrol-2-one (25)<smiles>O=C1C(Br)=C(Br)CN1c1cccc(O)c1</smiles>

The title compound was prepared according to Procedure A from mucobromic acid (1.20 g, $4.65 \mathrm{mmol})$, meta-aminophenol $(507.8 \mathrm{mg}, 4.65 \mathrm{mmol})$ and sodium triacetoxyborohydride (3.60 g, $13.95 \mathrm{mmol})$. The reaction mixture was left to stir for $48 \mathrm{~h}$. The precipitated solid was filtered by vacuum filtration, and a light brown solid was obtained (780 mg, 50\%); m.p. $164.0{ }^{\circ} \mathrm{C} ;{ }^{1} \mathrm{H} \mathrm{NMR}$ $\left(\mathrm{DMSO}-d_{6}, 300 \mathrm{MHz}\right): \delta 4.80\left(\mathrm{~s}, 2 \mathrm{H}, \mathrm{CH}_{2}\right), 6.57$ (m, 2H, ArH) , 7.05-7.27 (m, 2H, ArH), $\delta 9.59$ (s, $1 \mathrm{H}$, $\mathrm{OH}) ;{ }^{13} \mathrm{C}$ NMR (DMSO, $\left.75.5 \mathrm{MHz}\right): \delta 57.4\left(\mathrm{CH}_{2}\right), 106.6(\mathrm{ArCH}), 109.8(\mathrm{ArCH}), 112.2(\mathrm{ArCH}), 119.8(\mathrm{C})$, 130.2 (ArCH), $136.4(\mathrm{C}), 139.9(\mathrm{C}), 158.3(\mathrm{C}), 163.2(\mathrm{C}=\mathrm{O})$; IR (ATR): $v_{\max } 3257.5,1664.0,1597.9,1456.1$, 1392.4, 1255.0, 1213.9, 1039.0, 929.8, 867.1; UV (MeOH): $\lambda_{\max } 290.0 \mathrm{~nm}\left(\varepsilon 5893 \mathrm{~cm}^{-1} \mathrm{M}^{-1}\right)$; HRMS (ESI) $m / z$ calcd. for $\mathrm{C}_{10} \mathrm{H}_{7} \mathrm{Br}_{2} \mathrm{~N}_{1} \mathrm{O}_{2} \mathrm{Na}_{1} 353.8736[\mathrm{M}+\mathrm{Na}]^{+}$, found 353.8733 .

(18) N-(3-carboxyphenyl)-3,4-dichloro-1,5-dihydro-2H-pyrrol-2-one (26)<smiles>O=C(O)c1cccc(N2CC(Br)=C(Br)C2=O)c1</smiles>

The title compound was prepared from mucobromic acid (2.0 g, $7.75 \mathrm{mmol})$, meta-aminobenzoic acid $(1.06 \mathrm{~g}, 7.75 \mathrm{mmol})$ and sodium triacetoxyborohydride $(4.93 \mathrm{~g}, 23.26 \mathrm{mmol})$. The reaction mixture was left to stir for $24 \mathrm{~h}$. The precipitated solid was filtered by vacuum filtration to afford the product as pale yellow solid (0.36 g, 26\%). m.p. $186{ }^{\circ} \mathrm{C} ;{ }^{1} \mathrm{H}$ NMR $\left(300 \mathrm{MHz}, \mathrm{DMSO}-d_{6}\right) \delta 4.93\left(\mathrm{~s}, 2 \mathrm{H}, \mathrm{CH}_{2}\right)$, $\delta 7.55(\mathrm{t}, J=8.0 \mathrm{~Hz}, 1 \mathrm{H}, \mathrm{ArH}), \delta 7.73(\mathrm{tt}, J=8.0$ and $1.47 \mathrm{~Hz}, 1 \mathrm{H}, \mathrm{ArH}), \delta 7.89-7.93(\mathrm{~m}, 1 \mathrm{H}, \mathrm{ArH})$, $\delta 8.33(\mathrm{t}, J=1.8 \mathrm{~Hz}, 1 \mathrm{H}, \mathrm{ArH}), \delta 13.09$ (brs, $1 \mathrm{H}, \mathrm{COOH}) ;{ }^{13} \mathrm{C} \mathrm{NMR}\left(75.5 \mathrm{MHz}, \mathrm{DMSO}-d_{6}\right) \delta 57.3\left(\mathrm{CH}_{2}\right)$, $119.9(\mathrm{ArCH}), 123.3(\mathrm{ArCN}), 125.7(\mathrm{ArC}), 129.8(\mathrm{ArCH}), 136.9(\mathrm{ArCH}), 139.0(\mathrm{ArCH}), 146.0(2 \times \mathrm{CBr})$, $163.5(\mathrm{C}=\mathrm{O}), 167.4$ (C=O); IR (ATR): $v_{\max } 2821,2551,2321,1698,1584,1490,1425,1380,1312,1289,1227$, $1151,1032,939,901,840,757,673 \mathrm{~cm}^{-1}$; UV (THF): $\lambda_{\max } 239 \mathrm{~nm}\left(\varepsilon 15,683 \mathrm{~cm}^{-1} \mathrm{M}^{-1}\right), 291$ (6639); HRMS (ESI) $m / z$ calcd. for $\mathrm{C}_{11} \mathrm{H}_{7} \mathrm{Br}_{2} \mathrm{NO}_{3} \mathrm{Na} 381.8685[\mathrm{M}+\mathrm{Na}]^{+}$, found 381.8685 .

(19) $\mathrm{N}$-(4-carboxyphenyl)-3,4-dichloro-1,5-dihydro-2H-pyrrol-2-one (27) 


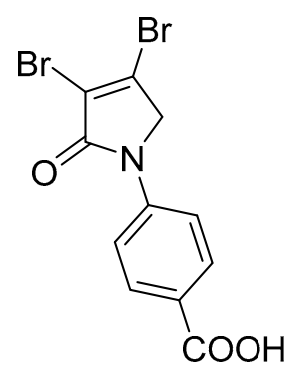

The title compound was synthesized from mucochloric acid ( $3 \mathrm{~g}, 11.63 \mathrm{mmol}), p$-aminobenzoic acid $(1.59 \mathrm{~g}, 11.63 \mathrm{mmol})$ and sodium triacetoxyborohydride $(7.39 \mathrm{~g}, 34.9 \mathrm{mmol})$ in 5:3 v/v dichloromethane/glacial acetic acid $(30 \mathrm{~mL})$. The reaction mixture was stirred and heated at $30{ }^{\circ} \mathrm{C}$ for $3 \mathrm{~h}$ during which time a precipitate was evident. The mixture was filtered under vacuum, and the solid was recrystallized in 1:9 acetone/methanol to get the desired product as a white solid (0.296 g, 7\%). m.p. $221{ }^{\circ} \mathrm{C} ;{ }^{1} \mathrm{H}$ NMR (300 MHz, DMSO- $\left.d_{6}\right) \delta 4.9\left(\mathrm{~s}, 2 \mathrm{H}, \mathrm{CH}_{2}\right), \delta 7.83(\mathrm{dd}, J=37.8$ and $8.7 \mathrm{~Hz}, 4 \mathrm{H}$, $\mathrm{ArH}), \delta 12.8$ (brs, $1 \mathrm{H}, \mathrm{COOH}) ;{ }^{13} \mathrm{C} \mathrm{NMR}\left(75.5 \mathrm{MHz}, \mathrm{DMSO}-d_{6}\right) \delta 57.2\left(\mathrm{CH}_{2}\right), 118.2(2 \times \mathrm{ArCH}), 120.0$ $(\mathrm{ArCN}), 126.6(\mathrm{ArC}), 130.9(2 \times \mathrm{ArCH}), 137.4(\mathrm{CBr}), 142.5(\mathrm{CBr}), 163.7(\mathrm{C}=\mathrm{O}), 167.1(\mathrm{C}=\mathrm{O})$; IR (ATR): $v_{\max } 2811,2659,2535,2112,1679,1601,1516,1423,1371,1275,1188,1145,1017,929,889,757,704 \mathrm{~cm}^{-1}$; UV (THF): $\lambda_{\max } 245 \mathrm{~nm}\left(\varepsilon 14,965 \mathrm{~cm}^{-1} \mathrm{M}^{-1}\right), 288(15,575) ; \mathrm{HRMS}$ (ESI) $m / z$ calcd. for $\mathrm{C}_{11} \mathrm{H}_{7} \mathrm{Br}_{2} \mathrm{NO}_{3} \mathrm{Na}$ $381.8685[\mathrm{M}+\mathrm{Na}]^{+}$, found 381.8684 .

(20) N-(4'-tert-butylphenylcarbamate)-3,4-dibromo-1,5-dihydro-2H-pyrrol-2-one (28)<smiles>CC(C)(C)OC(=O)Nc1ccc(N2CC(Br)=C(Br)C2=O)cc1</smiles>

The title compound was synthesized by reacting mucobromic acid (1 g, $3.87 \mathrm{mmol})$, $N$-Boc-p-phenylenediamine $(0.8 \mathrm{~g}, 3.87 \mathrm{mmol})$ and sodium triacetoxyborohydride $(2.46 \mathrm{~g}, 11.63 \mathrm{mmol})$ in 5:3 $v / v$ dichloromethane/glacial acetic acid $(10 \mathrm{~mL})$. The reaction mixture was left to stir at room temperature for $18 \mathrm{~h}$. The mixture was washed with water and brine and then extracted into ethyl acetate. The organic layer was dried over sodium sulphate and chromatographed on silica gel to yield the desired product as a yellow solid (0.6 g, 36\%). ${ }^{1} \mathrm{H} \mathrm{NMR}\left(300 \mathrm{MHz}, \mathrm{CDCl}_{3}\right) \delta 1.54\left(\mathrm{~s}, 9 \mathrm{H}, 3 \times \mathrm{CH}_{3}\right)$, $\delta 4.50\left(\mathrm{~s}, 2 \mathrm{H}, \mathrm{CH}_{2}\right), \delta 6.51(\mathrm{~s}, 1 \mathrm{H}, \mathrm{NH}), \delta 7.39-7.42(\mathrm{~m}, 2 \mathrm{H}, \mathrm{ArH}), \delta 7.54-7.59$ (m, 2H, ArH). ${ }^{13} \mathrm{C} \mathrm{NMR}$ $\left(75.5 \mathrm{MHz}, \mathrm{CDCl}_{3}\right) \delta 28.3\left(3 \times \mathrm{CH}_{3}\right), 57.2\left(\mathrm{CH}_{2}\right), 80.8(\mathrm{C}-\mathrm{O}), 119.2(2 \times \mathrm{ArCH}), 119.9(\mathrm{ArC}), 121.5(\mathrm{ArC})$, $132.9(2 \times \mathrm{ArCH}), 133.3(\mathrm{CBr}), 135.5(\mathrm{CBr}), 152.6(\mathrm{C}=\mathrm{O}), 163.1(\mathrm{C}=\mathrm{O})$; IR (ATR): $v_{\max }$ 3348, 3099, 2973, $1768,1688,1605,1518,1430,1364,1283,1232,1146,1020,846,739,680 \mathrm{~cm}^{-1}$; HRMS (ESI) $\mathrm{m} / z$ calcd. for $\mathrm{C}_{15} \mathrm{H}_{16} \mathrm{Br}_{2} \mathrm{~N}_{2} \mathrm{O}_{3} \mathrm{Na} 452.9420[\mathrm{M}+\mathrm{Na}]^{+}$, found 452.9422 .

(21) N-(4-aminophenyl)-3,4-dibromo-1,5-dihydro-2H-pyrrol-2-one (29) 
<smiles>Nc1ccc(N2CC(Br)=C(Br)C2=O)cc1</smiles>

The title compound was synthesized by following the same method used to synthesize Compound 19 to afford a yellow solid $\left(0.13\right.$ g, 28\%). m.p. $163{ }^{\circ} \mathrm{C} ;{ }^{1} \mathrm{H}$ NMR $\left(300 \mathrm{MHz}, \mathrm{DMSO}-d_{6}\right) \delta 4.70(\mathrm{~s}, 2 \mathrm{H}$, $\left.\mathrm{CH}_{2}\right), \delta 5.16$ (brs, $\left.1 \mathrm{H}, \mathrm{NH}_{2}\right), \delta$ 6.55-6.6 (m, 2H, ArH), 7.25-7.28 (m, 2H, ArH); ${ }^{13} \mathrm{C}$ NMR $(75.5 \mathrm{MHz}$, DMSO- $\left.d_{6}\right) \delta 57.0\left(\mathrm{CH}_{2}\right), 115.4(2 \times \mathrm{ArCH}), 121.6(2 \times \mathrm{ArCH}), 127.0(\mathrm{ArC}), 129.4(\mathrm{ArC}), 132.4(\mathrm{CBr})$, 144.2 (CBr), 164.2 (C=O); IR (ATR): $v_{\max } 3305,3208,2920,2287,1693,1611,1512,1442,1383,1280,1150$, 1023, 900, $830 \mathrm{~cm}^{-1}$; UV (ACN): $\lambda_{\max } 243\left(\varepsilon 8973 \mathrm{~cm}^{-1} \mathrm{M}^{-1}\right)$, 306 (3430); HRMS (ESI) $\mathrm{m} / z$ calcd. for $\mathrm{C}_{10} \mathrm{H}_{9} \mathrm{Br}_{2} \mathrm{~N}_{2} \mathrm{O} 330.9076[\mathrm{M}+\mathrm{H}]^{+}$, found 330.9075 .

(22) 3,4-dichloro-1-(4-hydroxyphenethyl)-1,5-dihydro-2H-pyrrol-2-one (30)<smiles>O=C1C(Cl)=C(Cl)CN1CCc1ccc(O)cc1</smiles>

The title compound was prepared according to Procedure A from mucochloric acid (700 mg, $4.14 \mathrm{mmol}$ ) and tyramine $(568.4 \mathrm{mg}, 4.14 \mathrm{mmol}$ ) and was left to react for 3 days. The crude mixture was poured into icy water, and the solid was collected and washed twice with ether. A light green solid was obtained (280 mg; $25 \%$ ). m.p. $157.8^{\circ} \mathrm{C} ;{ }^{1} \mathrm{H} \mathrm{NMR}\left(\mathrm{CDCl}_{3}, 300 \mathrm{MHz}\right): \delta 2.72\left(\mathrm{t}, J=7.2 \mathrm{~Hz}, 2 \mathrm{H}, \mathrm{CH}_{2}\right)$, $\delta 3.55\left(\mathrm{t}, J=7.2 \mathrm{~Hz}, 2 \mathrm{H}, \mathrm{CH}_{2}\right), \delta 4.2\left(\mathrm{~s}, 2 \mathrm{H}, \mathrm{C} 5-\mathrm{CH}_{2}\right), 6.67(\mathrm{~d}, J=8.4 \mathrm{~Hz}, 2 \mathrm{H}, \mathrm{ArH}), \delta 7.00(\mathrm{~d}, J=8.4 \mathrm{~Hz}$, $2 \mathrm{H}, \mathrm{ArH}), 9.22(\mathrm{~s}, 1 \mathrm{H}, \mathrm{OH}) .{ }^{13} \mathrm{C}$ NMR (DMSO, 75.5): $33.3\left(\mathrm{CH}_{2}\right), 44.6\left(\mathrm{CH}_{2}\right), 53.7\left(\mathrm{C}^{2}-\mathrm{CH}_{2}\right), 115.7$ $(\mathrm{ArCH}), 124.1$ ○, $129.0(\mathrm{C}), 130.0(\mathrm{ArCH}), 140.9(\mathrm{C}), 156.3(\mathrm{C}), 163.4(\mathrm{C}=\mathrm{O})$; IR (ATR): $v_{\max }$ 3237.6, 1670.5, 1513.3, 1451.15, 1279.3, 1219.1, 1169.4, 827.6; UV (MeOH): $\lambda_{\max } 277.0 \mathrm{~nm}\left(\varepsilon 19075.9 \mathrm{~cm}^{-1} \mathrm{M}^{-1}\right)$, 320 (2585.1); HRMS (ESI) $m / z$ calcd. for $\mathrm{C}_{12} \mathrm{H}_{11} \mathrm{Cl}_{2} \mathrm{~N}_{1} \mathrm{O}_{2} \mathrm{Na}_{1} 294.0059[\mathrm{M}+\mathrm{Na}]^{+}$, found 294.0060.

(23) 1-(2-(1H-indol-3-yl)ethyl)-3,4-dichloro-1,5-dihydro-2H-pyrrol-2-one (31)<smiles>O=C1C(Cl)=C(Cl)CN1CCc1c[nH]c2ccccc12</smiles>

The title compound was prepared according to Procedure A from mucochloric acid ( $200 \mathrm{mg}$, $1.18 \mathrm{mmol})$ and tryptamine $(189.7 \mathrm{mg}, 1.18 \mathrm{mmol})$ and was left to react for $24 \mathrm{~h}$. The crude mixture was extracted with dichloromethane $(30 \mathrm{~mL})$ and washed with water $(15 \mathrm{~mL})$ followed by brine $(15 \mathrm{~mL})$, dried over sodium sulphate, and the solvent was evaporated. The oil residue was then triturated with methanol, and the precipitated solid was filtered to yield a green solid (145 mg; $42 \%$ ). m.p. 
$159.3{ }^{\circ} \mathrm{C} ;{ }^{1} \mathrm{H}$ NMR (DMSO, $\left.400 \mathrm{MHz}\right): \delta 2.96\left(\mathrm{t}, J=7.3 \mathrm{~Hz}, \mathrm{CH}_{2}\right), 3.67\left(t, J=7.3>\mathrm{N}-\mathrm{CH}_{2}\right), 7.07(\mathrm{~s}, 1 \mathrm{H}$, $\mathrm{ArH}), \delta 7.16(\mathrm{t}, J=7.7,14.8 \mathrm{~Hz}, 1 \mathrm{H}, \mathrm{ArH}), \delta 7.22(\mathrm{t}, J=7.0,14.8 \mathrm{~Hz}, 1 \mathrm{H}, \mathrm{ArH}), \delta 7.40(\mathrm{~d}, J=8.1 \mathrm{~Hz}$, $1 \mathrm{H}), \delta 7.61(\mathrm{~d}, J=8.1 \mathrm{~Hz}, 1 \mathrm{H}, \mathrm{ArH}), 10.84(1 \mathrm{H}, \mathrm{NH}) .{ }^{13} \mathrm{C}$ NMR (DMSO, $\left.100 \mathrm{MHz}\right): \delta 24.2\left(\mathrm{CH}_{2}\right)$, $43.6\left(\mathrm{CH}_{2}\right), 54.0\left(\mathrm{C}_{-}-\mathrm{CH}_{2}\right), 111.3$ C $, 111.9(\mathrm{ArCH}), 118.6(\mathrm{ArCH}), 118.8(\mathrm{ArCH}), 121.5(\mathrm{ArCH}), 123.3$ (ArCH), 124.2 (C), 127.5 (ArC), 136.7 (ArC), 140.9 (C), 163.5 (C=O); IR (ATR): $v_{\max } 3277.5,3058.0,2918.1$, $1772.8,1678.8,1452.1,1364.8,1298.4,1099.1,1036.7,974.5,852.9,738.8 ; \mathrm{UV}(\mathrm{MeOH}): \lambda_{\max } 275.0 \mathrm{~nm}$ ( $\left.\varepsilon 3463.2 \mathrm{~cm}^{-1} \mathrm{M}^{-1}\right), 220.0 \mathrm{~nm}$ (15204.8); HRMS (ESI) $\mathrm{m} / z$ calcd. for $\mathrm{C}_{14} \mathrm{H}_{12} \mathrm{Cl}_{2} \mathrm{~N}_{2} \mathrm{O}_{1} \mathrm{Na}_{1} 317.02189$ $[\mathrm{M}+\mathrm{Na}]^{+}$, found 317.02188 .

(24) N-butyl-4-(3,4-dichloro-2-oxo-2,5-dihydro-1H-pyrrol-1-yl)benzamide (32)<smiles>CCCCNC(=O)c1ccc(N2CC(Cl)=C(Cl)C2=O)cc1</smiles>

The title compound was prepared from acid $19(200 \mathrm{mg}, 0.74 \mathrm{mmol})$ and butylamine (53.8 $\mathrm{mg}$, $0.74 \mathrm{mmol}$ ) according to the general Procedure B. The solvent of the reaction mixture was evaporated then triturated with methanol, and the precipitated solid was filtered. A beige solid was obtained (40 mg; 17\%). m.p. $168.5^{\circ} \mathrm{C}^{1}{ }^{1} \mathrm{H}$ NMR (DMSO- $\left.d_{6}, 600 \mathrm{MHz}\right): \delta 0.99\left(\mathrm{t}, J=7.4 \mathrm{~Hz}, 3 \mathrm{H}, \mathrm{CH}_{3}\right), 1.23-1.34(\mathrm{~m}$, $\left.4 \mathrm{H}, 2 \times \mathrm{CH}_{2}\right), 1.50\left(\mathrm{~m}, 2 \mathrm{H}, \mathrm{CH}_{2}\right), 4.89\left(\mathrm{~s}, 2 \mathrm{H}, \mathrm{C} 5-\mathrm{CH}_{2}\right), 7.80(\mathrm{~d}, J=8.9 \mathrm{~Hz}, 2 \mathrm{H}, \mathrm{ArH}), 7.89(\mathrm{~d}, J=8.9 \mathrm{~Hz}$, 2H, ArH), $8.41(\mathrm{~s}, 1 \mathrm{H}, \mathrm{NH}) .{ }^{13} \mathrm{C}$ NMR (DMSO-d $\left.6,150.9 \mathrm{MHz}\right): \delta 14.11\left(\mathrm{CH}_{3}\right), 20.11\left(\mathrm{CH}_{2}\right), 31.71\left(\mathrm{CH}_{2}\right)$, $53.92\left(\mathrm{C} 5-\mathrm{CH}_{2}\right), 118.26(\mathrm{ArCH}), 124.2(\mathrm{C}), 129.60(\mathrm{ArCH}), 130.8(\mathrm{C}), 141.0(\mathrm{C}), 142.5(\mathrm{C}), 162.7(\mathrm{C}=\mathrm{O})$, 165.7 (C=O); IR (ATR): $v_{\max } 3314.7,3078.0,2955.3,1696.7,1606.9,1508.1,1381.5,1152.3,835.7,763.2$; UV (MeOH): $\lambda_{\max } 300.0 \mathrm{~nm}\left(\varepsilon\right.$ 10,897.6 cm $\mathrm{cm}^{-1}$ ); HRMS (ESI) $m / z$ calcd. for $\mathrm{C}_{15} \mathrm{H}_{16} \mathrm{Cl}_{2} \mathrm{~N}_{2} \mathrm{O}_{2} \mathrm{Na}_{1}$ $349.0481[\mathrm{M}+\mathrm{Na}]^{+}$, found 349.0482 .

(25) 4-(3,4-dichloro-2-oxo-2,5-dihydro-1H-pyrrol-1-yl)-N-hexylbenzamide (33)<smiles>CCCCCCNC(=O)c1ccc(N2CC(Cl)=C(Cl)C2=O)cc1</smiles> 
The title compound was prepared from acid $19(200 \mathrm{mg}, 0.74 \mathrm{mmol} \mathrm{mmol})$ and hexylamine (74.4 $\mathrm{mg}, 0.74 \mathrm{mmol}$ ) according to the general Procedure B. The solvent of the reaction mixture was evaporated then triturated with methanol, and the precipitated solid was filtered. A white solid was obtained (75 mg; 29\%); m.p. $159.5{ }^{\circ} \mathrm{C} ;{ }^{1} \mathrm{H}$ NMR (DMSO- $\left.d_{6}, 400 \mathrm{MHz}\right): \delta 0.88(\mathrm{t}, J=6.9 \mathrm{~Hz}$, $\left.3 \mathrm{H}, \mathrm{CH}_{3}\right), 1.18-1.21\left(\mathrm{~m}, 6 \mathrm{H}, 3 \times \mathrm{CH}_{2}\right), 1.28-1.53\left(\mathrm{~m}, 2 \mathrm{H}, \mathrm{CH}_{2}\right), 3.06-3.09\left(\mathrm{~m}, 2 \mathrm{H}, \mathrm{CH}_{2}\right), 4.90(\mathrm{~s}, 2 \mathrm{H}$, $\left.\mathrm{CH}_{2}\right), 7.81(\mathrm{~d}, J=8.4 \mathrm{~Hz}, 2 \mathrm{H}, \mathrm{ArH}), 7.90(\mathrm{~d}, J=8.4 \mathrm{~Hz}, 2 \mathrm{H}, \mathrm{ArH}), 8.43(\mathrm{~s}, \mathrm{NH}) .{ }^{13} \mathrm{C}$ NMR (DMSO- $d_{6}$, $100 \mathrm{MHz}): \delta 22.5\left(\mathrm{CH}_{3}\right), 26.7\left(\mathrm{CH}_{2}\right), 29.6\left(\mathrm{CH}_{2}\right), 31.5\left(\mathrm{CH}_{2}\right), 39.7\left(\mathrm{CH}_{2}\right), 45.9\left(\mathrm{CH}_{2}\right), 54.0\left(\mathrm{C}_{-}-\mathrm{CH}_{2}\right), 120.0$ $(\mathrm{ArCH}), 124.2(\mathrm{C}), 128.6(\mathrm{ArCH}), 130.8(\mathrm{C}), 140.9$ (C), 142.4 (C), 162.7 (C=O, $165.7(\mathrm{C}=\mathrm{O})$. IR (ATR): $v_{\max } 3331.8,2929.2,1691.9,1630.4,1503.6,1377.3,1270.6,1151.8,927.3,846.7 ;$ UV $(\mathrm{MeOH}): \lambda_{\max }$ $280.0 \mathrm{~nm}\left(\varepsilon 6522.5 \mathrm{~cm}^{-1} \mathrm{M}^{-1}\right)$; HRMS (ESI) $\mathrm{m} / z$ calcd. for $\mathrm{C}_{17} \mathrm{H}_{20} \mathrm{Cl}_{2} \mathrm{~N}_{2} \mathrm{O}_{2} \mathrm{Na}_{1} 377.0794[\mathrm{M}+\mathrm{H}]^{+}$, found 377.0792 .

(26) N-benzyl-4-(3,4-dichloro-2-oxo-2,5-dihydro-1H-pyrrol-1-yl)benzamide (34)<smiles>O=C(NCc1ccccc1)c1ccc(N2CC(Cl)=C(Cl)C2=O)cc1</smiles>

The title compound was prepared from 4-(3,4-dichloro-2-oxo-2,5-dihydro-1H-pyrrol-1-yl)benzoic acid (19) $(200 \mathrm{mg}, 0.74 \mathrm{mmol} \mathrm{mmol})$ and benzylamine $(117.8 \mathrm{mg}, 1.1 \mathrm{mmol})$ according to the general Procedure B. The precipitated solid was collected by filtration and washed with $1 \mathrm{~mL}$ of water, followed by hexane, then triturated from methanol. A white solid was obtained $(230 \mathrm{mg} ; 76 \%)$. m.p. $175.3^{\circ} \mathrm{C}$; ${ }^{1} \mathrm{H}$ NMR (DMSO- $\left.d_{6}, 400 \mathrm{MHz}\right): \delta 3.96\left(\mathrm{~s}, 2 \mathrm{H}, \mathrm{CH}_{2}\right), 4.90\left(\mathrm{~s}, 2 \mathrm{H}, \mathrm{C} 5-\mathrm{CH}_{2}\right), 7.21-7.46(\mathrm{~m}, 6 \mathrm{H}, \mathrm{ArH}$ and $\mathrm{NH}), 7.80(\mathrm{~d}, J=8.8 \mathrm{~Hz}, 2 \mathrm{H}, \mathrm{ArH}), 7.96(\mathrm{~d}, J=8.8,2 \mathrm{H}, \mathrm{ArH}) .{ }^{13} \mathrm{C}$ NMR (DMSO- $\left.d_{6}, 400 \mathrm{MHz}\right): \delta 54.0$ $\left(\mathrm{C} 5-\mathrm{CH}_{2}\right), 67.5\left(\mathrm{CH}_{2}\right), 118.2(\mathrm{ArCH}), 124.2(\mathrm{C}), 127.7(\mathrm{ArC}), 128.3(\mathrm{ArC}), 128.4(\mathrm{ArCH}), 128.7(\mathrm{ArCH})$, $128.9(\mathrm{ArCH}), 130.8(\mathrm{C}), 142.4(\mathrm{C}), 162.8(\mathrm{C}=\mathrm{O}), 167.8(\mathrm{C}=\mathrm{O})$. IR (ATR): $v_{\max } 2824.5,2641.0,1699.5,1604$, 1510.0, 1366.2, 1305.9, 1152.1, 782.0; UV (MeOH): $\lambda_{\max } 285.0 \mathrm{~nm}\left(\varepsilon 3272.6 \mathrm{~cm}^{-1} \mathrm{M}^{-1}\right)$; HRMS (ESI) $\mathrm{m} / z$ calcd. for $\mathrm{C}_{18} \mathrm{H}_{15} \mathrm{Cl}_{2} \mathrm{~N}_{2} \mathrm{O}_{2} 361.0505[\mathrm{M}+\mathrm{H}]^{+}$, found 361.0501.

(27) Synthesis of N-(2-(1H-indol-3-yl)ethyl)-4-(3,4-dichloro-2-oxo-2,5-dihydro-1H-pyrrol-1-yl) benzamide (35)<smiles>O=C(NCCc1c[nH]c2ccccc12)c1ccc(N2CC(Cl)=C(Cl)C2=O)cc1</smiles> 
The title compound was prepared from 4-(3,4-dichloro-2-oxo-2,5-dihydro-1H-pyrrol-1-yl)benzoic acid (19) $(300 \mathrm{mg}, 1.10 \mathrm{mmol})$ and tryptamine $(176.7 \mathrm{mg}, 1.1 \mathrm{mmol})$ according to the general Procedure B. The precipitated solid was collected by filtration and washed with $(1 \mathrm{~mL})$ water, followed by hexane, then the solid was triturated from methanol to yield a pale pink solid (400 mg, 88\%); m.p. $149.8^{\circ} \mathrm{C} ;{ }^{1} \mathrm{H}$ NMR (DMSO- $\left.d_{6}, 400 \mathrm{~Hz}\right): \delta 2.52\left(\mathrm{~m}, 2 \mathrm{H}, \mathrm{CH}_{2}\right), 3.32\left(\mathrm{~m}, 2 \mathrm{H}, \mathrm{CH}_{2}\right), 4.88\left(\mathrm{~S}, 2 \mathrm{H}, \mathrm{C} 5-\mathrm{CH}_{2}\right)$, $6.99(\mathrm{t}, J=7.0 \mathrm{~Hz}, 1 \mathrm{H}, \mathrm{ArH}), \delta 7.08(\mathrm{t}, J=7.0 \mathrm{~Hz}, 1 \mathrm{H}, \mathrm{ArH})), \delta 7.22(\mathrm{~s}, 1 \mathrm{H}, \mathrm{NH}), \delta 7.36(\mathrm{~d}, J=8.0 \mathrm{~Hz}$, $1 \mathrm{H}, \mathrm{ArH}), \delta 7.55(\mathrm{~d}, J=8.0 \mathrm{~Hz}, 1 \mathrm{H}, \mathrm{ArH}), 7.75(\mathrm{~d}, J=8.8 \mathrm{~Hz}, 2 \mathrm{H}, \mathrm{ArH}), 7.94(\mathrm{~d}, J=8.8 \mathrm{~Hz}, 2 \mathrm{H}, \mathrm{ArH})$, $10.94(\mathrm{~s}, \mathrm{CONH}) .{ }^{13} \mathrm{C}$ NMR (DMSO- $\left.d_{6}, 100 \mathrm{MHz}\right): \delta 23.4\left(\mathrm{CH}_{2}\right), 46.1\left(\mathrm{CH}_{2}\right), 53.8\left(\mathrm{CH}_{2}\right), 83.01(\mathrm{ArC})$, 109.82 (ArCH), $112.04(\mathrm{ArCH}), 118.53(\mathrm{ArCH}), 119.03(\mathrm{ArCH}), 120.15(\mathrm{ArCH}), 121.7(\mathrm{ArCH}), 123.8$ @ , 130.6 (ArCH), $136.7(\mathrm{ArCH}), 141.2(\mathrm{ArC}), 142.37(\mathrm{ArC}), 142.85(\mathrm{ArC}), 153.0(\mathrm{C}), 166.35(\mathrm{C}=\mathrm{O}), 167.4$ (C=O); IR (ATR): $v_{\max } 3223.4,2902.4,1700.1,1603.1,1370.0,1248,1038.6,843.4,781.0, \mathrm{UV}(\mathrm{MeOH}): \lambda_{\max }$ $280.0 \mathrm{~nm}\left(\varepsilon 3802.5 \mathrm{~cm}^{-1} \mathrm{M}^{-1}\right)$; HRMS (ESI) $\mathrm{m} / z$ calcd. for $\mathrm{C}_{21} \mathrm{H}_{17} \mathrm{Cl}_{2} \mathrm{~N}_{3} \mathrm{O}_{2} \mathrm{Na}_{1} 436.0590[\mathrm{M}+\mathrm{Na}]^{+}$, found 436.0583 .

(28) 4-(3,4-dichloro-2-oxo-2,5-dihydro-1H-pyrrol-1-yl)-N-(2-morpholinoethyl)benzamide (36)<smiles>O=C(NCCN1CCOCC1)c1ccc(N2CC(Cl)=C(Cl)C2=O)cc1</smiles>

The title compound was prepared from 4-(3,4-dichloro-2-oxo-2,5-dihydro-1H-pyrrol-1-yl)benzoic acid (19) $(200 \mathrm{mg}, 0.74 \mathrm{mmol} \mathrm{mmol})$ and 2-morpholinoethan-1-amine ( $95.7 \mathrm{mg}, 0.74 \mathrm{mmol}$ ) according to Procedure B. After the completion of the reaction, the crude mixture was dissolved in ethanol, and few drops of diethyl ether were added dropwise. Then, the black solid impurity was filtered and discarded. The yellow filtrate was evaporated to dryness then recrystallized from ethanol, and a yellow small needle crystal was obtained (7 mg; $3 \%$ ). m.p. $129.1{ }^{\circ} \mathrm{C} ;{ }^{1} \mathrm{H}$ NMR (DMSO- $d_{6}, 600 \mathrm{MHz}$ ): $\delta 3.05-3.13$ $\left(\mathrm{m}, 4 \mathrm{H}, 2 \times \mathrm{CH}_{2}\right), 3.55\left(\mathrm{~d}, J=12 \mathrm{~Hz}, 2 \mathrm{H}, \mathrm{CH}_{2}\right), 3.68\left(\mathrm{~d}, J=6.0 \mathrm{~Hz}, 2 \mathrm{H}, \mathrm{CH}_{2}\right), 3.79(\mathrm{t}, J=12.0 \mathrm{~Hz}, 2 \mathrm{H}$, $\left.\mathrm{CH}_{2}\right), 3.98\left(\mathrm{~d}, J=12.0,2 \mathrm{H}, \mathrm{CH}_{2}\right), 4.91\left(\mathrm{~s}, 2 \mathrm{H}, \mathrm{C} 5-\mathrm{CH}_{2}\right), 7.84(\mathrm{~d}, J=8.6,2 \mathrm{H}, \mathrm{ArH}), 7.98(\mathrm{~d}, J=8.6 \mathrm{~Hz}, 2 \mathrm{H}$, $\mathrm{ArH}), 8.87(\mathrm{~s}, \mathrm{NH}) .{ }^{13} \mathrm{C}$ NMR (DMSO-d $\left.d_{6}, 100 \mathrm{MHz}\right): \delta 34.2\left(\mathrm{CH}_{2}\right), 46.0\left(\mathrm{CH}_{2}\right), 51.7\left(\mathrm{CH}_{2}\right), 54.0\left(\mathrm{CH}_{2}\right)$, $63.6\left(\mathrm{CH}_{2}\right), 118.3(\mathrm{ArCH}), 124.2 \mathrm{C}, 129.0(\mathrm{ArCH}), 131.0(\mathrm{C}), 141.4(\mathrm{C}), 142.7(\mathrm{C}), 162.8(\mathrm{C}=\mathrm{O})$; IR (ATR): $v_{\max } 3307.4,2923.8,1699.1,1603.7,1509.0,1370.2,1110.5,782.0 ; \mathrm{UV}(\mathrm{MeOH}): \lambda_{\max } 285.0 \mathrm{~nm}$ $\left(\varepsilon 6378.6 \mathrm{~cm}^{-1} \mathrm{M}^{-1}\right.$ ); HRMS (ESI) $\mathrm{m} / z$ calcd. for $\mathrm{C}_{17} \mathrm{H}_{20} \mathrm{Cl}_{2} \mathrm{~N}_{3} \mathrm{O}_{3} 384.0876[\mathrm{M}+\mathrm{H}]^{+}$, found 384.0879 .

(29) 4-(3,4-dichloro-2-oxo-2,5-dihydro-1H-pyrrol-1-yl)- $\mathrm{N}$-(3-morpholinopropyl)benzamide (37) 
<smiles>O=C(NCCCN1CCOCC1)c1ccc(N2CC(Cl)=C(Cl)C2=O)cc1</smiles>

The title compound was prepared from 4-(3,4-dichloro-2-oxo-2,5-dihydro-1H-pyrrol-1-yl)benzoic acid (19) (300 mg, $1.1 \mathrm{mmol} \mathrm{mmol}$ ) and 3-morpholinopropan-1-amine (160 mg, $1.1 \mathrm{mmol}$ ) according to the general Procedure B. The precipitated solid was filtered, washed with ether and hexane to yield a light beige solid (180 mg; 50\%). m.p. $129.1{ }^{\circ} \mathrm{C} ;{ }^{1} \mathrm{H}$ NMR (DMSO- $\left.d_{6}, 400 \mathrm{MHz}\right): \delta 1.70-1.74(\mathrm{~m}, 2 \mathrm{H}$, $\left.\mathrm{CH}_{2}\right), 2.34-2.41\left(\mathrm{~m}, 10 \mathrm{H}, 5 \times \mathrm{CH}_{2}\right), 2.53\left(\mathrm{t}, J=5.4,10.0,2 \mathrm{H}, \mathrm{CH}_{2}\right), 4.88\left(\mathrm{~s}, 2 \mathrm{H}, \mathrm{C} 5-\mathrm{CH}_{2}\right), 7.72(\mathrm{~d}, J=8.8$, $2 \mathrm{H}, \mathrm{ArH}), 7.91\left(\mathrm{~d}, J=8.8,2 \mathrm{H}\right.$ ArH and NH), ${ }^{13} \mathrm{C}$ NMR (DMSO- $\left.d_{6}, 100 \mathrm{MHz}\right): \delta 23.91\left(\mathrm{CH}_{2}\right), 38.8$ $\left(\mathrm{CH}_{2}\right), 53.3\left(\mathrm{CH}_{2}\right), 55.97\left(\mathrm{CH}_{2}\right), 66.34\left(\mathrm{CH}_{2}\right), 117.9(\mathrm{ArCH}), 124.8 \odot, 129.9(\mathrm{ArCH}), 134.2(\mathrm{ArC}), 139.9$ (C), 141.44 (C), 163.18 (C=O), 173.09 (C=O). IR (ATR): $v_{\max } 3372.1,3078.2,2934.0,1695.2,1531.4,1370.7$, 1110.8, 1042.2, 778.6; UV (MeOH): $\lambda_{\max } 285.0 \mathrm{~nm}\left(\varepsilon 2695.1 \mathrm{~cm}^{-1} \mathrm{M}^{-1}\right)$; HRMS (ESI) $m / z$ calcd. for $\mathrm{C}_{18} \mathrm{H}_{22} \mathrm{Cl}_{2} \mathrm{~N}_{3} \mathrm{O}_{3} 398.1033[\mathrm{M}+\mathrm{H}]^{+}$, found 398.1030.

(30) 4-(3,4-dichloro-2-oxo-2,5-dihydro-1H-pyrrol-1-yl)-N-(3-(piperidin-1-yl)propyl)benzamide (38)<smiles>O=C(NCCCN1CCCCC1)c1ccc(N2CC(Cl)=C(Cl)C2=O)cc1</smiles>

The title compound was prepared from 4-(3,4-dichloro-2-oxo-2,5-dihydro-1H-pyrrol-1-yl)benzoic acid (19) (200 mg, $0.74 \mathrm{mmol} \mathrm{mmol}$ ) and 3-(piperidin-1-yl)propan-1-amine (104.6 mg, $0.74 \mathrm{mmol}$ ) according to the general Procedure B. The solid product was collected by filtration, washed with water and hexane to yield a beige solid (64 mg; $27 \%$ ). m.p. $165.5^{\circ} \mathrm{C} ;{ }^{1} \mathrm{H}$ NMR DMSO- $d_{6}, 600 \mathrm{MHz}$ ): $\delta 1.24-1.38\left(\mathrm{~m}, 8 \mathrm{H}, 4 \times \mathrm{CH}_{2}\right), 1.46-1.48\left(\mathrm{~m}, 4 \mathrm{H}, 2 \times \mathrm{CH}_{2}\right), 1.98-2.00\left(\mathrm{~m}, 2 \mathrm{H}, \mathrm{CH}_{2}\right), 2.01-2.3(\mathrm{~m}, 2 \mathrm{H}$, $\left.\mathrm{CH}_{2}\right), 4.90\left(\mathrm{~s}, 2 \mathrm{H}, \mathrm{C} 5-\mathrm{CH}_{2}\right), 5.32(\mathrm{~s}, \mathrm{NH}), 7.79(\mathrm{~d}, J=8.2 \mathrm{~Hz}, 2 \mathrm{H}, \mathrm{ArH}), 7.95(\mathrm{~d}, J=8.2 \mathrm{~Hz}, 2 \mathrm{H}, \mathrm{ArH})$. ${ }^{13} \mathrm{C}$ NMR (DMSO- $\left.d_{6}, 100 \mathrm{MHz}\right): \delta 22.3\left(\mathrm{CH}_{2}\right), 25.5\left(\mathrm{CH}_{2}\right), 26.4\left(\mathrm{CH}_{2}\right), 29.1\left(\mathrm{CH}_{2}\right), 31.3\left(\mathrm{CH}_{2}\right), 39.7$ $\left(\mathrm{CH}_{2}\right), 46.4\left(\mathrm{CH}_{2}\right), 118.1(\mathrm{ArCH}), 124.8 @ 128.0(\mathrm{ArC}), 129.5(\mathrm{ArCH}), 130.5(\mathrm{C}), 140.9(\mathrm{C}), 163.2(\mathrm{C}=\mathrm{O})$, 
167.8 (C=O). IR (ATR): $v_{\max } 3355.8,2936.3,16887.5,1540.6,1375.5,1042.7,850.0,775.0 ; \mathrm{UV}$ (MeOH): $\lambda_{\max } 285.0 \mathrm{~nm}\left(\varepsilon 7022.6 \mathrm{~cm}^{-1} \mathrm{M}^{-1}\right)$; HRMS (ESI) $\mathrm{m} / z$ calcd. for $\mathrm{C}_{19} \mathrm{H}_{24} \mathrm{Cl}_{2} \mathrm{~N}_{3} \mathrm{O}_{2} 396.1240[\mathrm{M}+\mathrm{H}]^{+}$, found 396.1234 .

(31) N-(4-(3,4-dichloro-2-oxo-2,5-dihydro-1H-pyrrol-1-yl)phenyl)butyramide (39)<smiles>CCCC(=O)Nc1ccc(N2CC(Cl)=C(Cl)C2=O)cc1</smiles>

The title compound was prepared from 1-(4-aminophenyl)-3,4-dichloro-1,5-dihydro-2H-pyrrol-2one (23) (200 mg, $0.82 \mathrm{mmol})$ and butyryl chloride $(87.7 \mathrm{mg}, 0.82 \mathrm{mmol})$ according to the general Procedure C. After completion of the reaction, the crude mixture was evaporated to complete dryness, followed by trituration from methanol, then washed with $1 \mathrm{~mL}$ of ether twice; the solid was collected by filtration and dried in high vac. An off-white solid was obtained (89 mg, 31\%). m.p. $195.5{ }^{\circ} \mathrm{C}$; ${ }^{1} \mathrm{H} \mathrm{NMR}$ (DMSO- $\left.d_{6}, 400 \mathrm{MHz}\right): \delta 0.91\left(\mathrm{t}, J=7.3 \mathrm{~Hz}, 3 \mathrm{H}, \mathrm{CH}_{3}\right), 1.58-1.64\left(\mathrm{~m}, 2 \mathrm{H}, \mathrm{CH}_{2}\right), 2.26(\mathrm{t}, J=7.3 \mathrm{~Hz}$, 2H), 4.82 (s, 2H, C5-CH $), 7.62$ (brs, $4 \mathrm{H}, \mathrm{ArH}), 9.92(\mathrm{~s}, \mathrm{NH}) .{ }^{13} \mathrm{C}$ NMR (DMSO-d, $\left.100 \mathrm{MHz}\right): \delta 14.1$ $\left(\mathrm{CH}_{2}\right), 19.0\left(\mathrm{CH}_{2}\right), 54.1\left(\mathrm{CH}_{2}\right), 120.0(\mathrm{ArCH}), 120.1(\mathrm{ArCH}), 124.3 \mathrm{C}, 134.0(\mathrm{C}), 136.6(\mathrm{C}), 141.6(\mathrm{C}), 162.2$ (C), 171.5 (C=O); IR (ATR): $v_{\max } 3343.2,2961.6,1677.3,1522.0,1408.4,1283.0,820.6$; UV (MeOH): $\lambda_{\max }$ $290.0 \mathrm{~nm}\left(\varepsilon 8377.5 \mathrm{~cm}^{-1} \mathrm{M}^{-1}\right)$; HRMS (ESI) $m / z$ calcd. for $\mathrm{C}_{14} \mathrm{H}_{24} \mathrm{Cl}_{2} \mathrm{~N}_{2} \mathrm{O}_{2} \mathrm{Na}_{1} 335.0325[\mathrm{M}+\mathrm{Na}]^{+}$, found 335.0323 .

(32) N-(4-(3,4-dichloro-2-oxo-2,5-dihydro-1H-pyrrol-1-yl)phenyl)hexanamide (40)

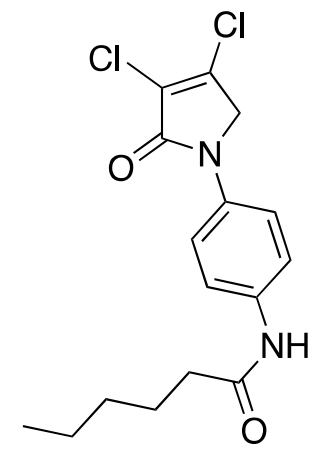

The title compound was prepared from 1-(4-aminophenyl)-3,4-dichloro-1,5-dihydro-2H-pyrrol-2one (23) (200 mg, $0.82 \mathrm{mmol}$ ) and hexanoyl chloride (110.7 mg, $0.82 \mathrm{mmol}$ ) according to Procedure C. After completion of the reaction, the crude mixture was evaporated to complete dryness, followed by trituration from methanol, then the solid was washed with $1 \mathrm{~mL}$ of ether twice. The solid was collected by filtration and dried in high vac. An off-white solid was obtained (164 mg; 52\%). m.p. $225.7{ }^{\circ} \mathrm{C} ;{ }^{1} \mathrm{H}$ NMR (DMSO-d $\left.6,300 \mathrm{MHz}\right): \delta 0.93\left(\mathrm{t}, J=7.0 \mathrm{~Hz}, 3 \mathrm{H}, \mathrm{CH}_{3}\right), 1.38(\mathrm{~d}, J=3.6 \mathrm{~Hz}, 4 \mathrm{H}$, $\left.2 \times \mathrm{CH}_{2}\right), 1.73-1.79\left(\mathrm{~m}, 2 \mathrm{H}, \mathrm{CH}_{2}\right), 2.38\left(\mathrm{t}, J=7.47 \mathrm{~Hz}, 2 \mathrm{H}, \mathrm{CH}_{2}\right), 4.49\left(\mathrm{~s}, 2 \mathrm{H}, \mathrm{C} 5-\mathrm{CH}_{2}\right), 7.18(\mathrm{~s}, \mathrm{NH})$, 7.59 (brs, 4H, ArH). ${ }^{13} \mathrm{C} \mathrm{NMR}\left(\mathrm{CDCl}_{3}, 75.5 \mathrm{MHz}\right): 14.3\left(\mathrm{CH}_{2}\right), 22.4\left(\mathrm{CH}_{2}\right), 25.2\left(\mathrm{CH}_{2}\right), 31.4\left(\mathrm{CH}_{2}\right)$, $36.8\left(\mathrm{CH}_{2}\right), 54.1\left(\mathrm{CH}_{2}\right), 119.9(\mathrm{ArCH}), 120.1(\mathrm{ArCH}), 124.3(\mathrm{C}), 133.8(\mathrm{C}), 136.7(\mathrm{C}), 141.6(\mathrm{C}), 162.2$ (C), 171.7 (C); IR (ATR): $v_{\max } 3358.6,2949.4,1677.3,1515.9,1413.1,1515.9,1284.3,1042.8,853.0 ;$ UV 
(MeOH): $\lambda_{\max } 290.0 \mathrm{~nm}\left(\varepsilon 8394.3 \mathrm{~cm}^{-1} \mathrm{M}^{-1}\right)$; HRMS (ESI) $\mathrm{m} / z$ calcd. for $\mathrm{C}_{16} \mathrm{H}_{18} \mathrm{Cl}_{2} \mathrm{~N}_{2} \mathrm{O}_{2} \mathrm{Na}_{1} 363.0638$ $[\mathrm{M}+\mathrm{Na}]^{+}$, found 363.0636 .

(33) N-(4-(3,4-dichloro-2-oxo-2,5-dihydro-1H-pyrrol-1-yl)phenyl)octanamide (41)

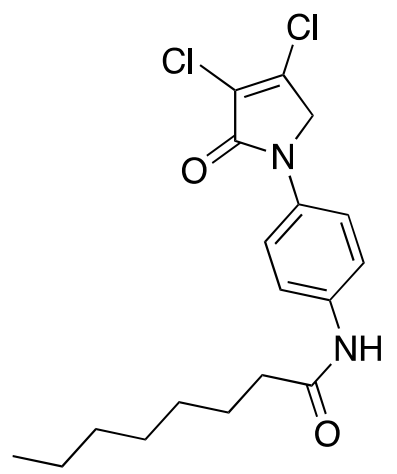

The title compound was prepared from 1-(4-aminophenyl)-3,4-dichloro-1,5-dihydro-2H-pyrrol-2one (23) $(200 \mathrm{mg}, 0.82 \mathrm{mmol})$ and octanoyl chloride $(133.8 \mathrm{mg}, 0.82 \mathrm{mmol})$ according to Procedure C. After completion of the reaction, the crude mixture was evaporated to complete dryness, followed by trituration from methanol and then washed with $1 \mathrm{~mL}$ of ether twice. The solid was collected by filtration and dried in high vac. A white solid was obtained (140 mg; 44\%). m.p. $194.1{ }^{\circ} \mathrm{C} ;{ }^{1} \mathrm{H} \mathrm{NMR}$ $\left(\mathrm{CDCl}_{3}, 300 \mathrm{MHz}\right): 0.91\left(\mathrm{t}, J=6.8 \mathrm{~Hz}, 3 \mathrm{H}, \mathrm{CH}_{3}\right), 1.31-1.40\left(\mathrm{~m}, 4 \mathrm{H}, 2 \times \mathrm{CH}_{2}\right), 1.58$ (brs, $\left.4 \mathrm{H}, 2 \times \mathrm{CH}_{2}\right)$, $1.75\left(\mathrm{~m}, 2 \mathrm{H}, \mathrm{CH}_{2}\right), 2.38\left(\mathrm{t}, J=7.7 \mathrm{~Hz}, 2 \mathrm{H}, \mathrm{CH}_{2}\right), 4.50\left(\mathrm{~s}, 2 \mathrm{H}, \mathrm{C} 5-\mathrm{CH}_{2}\right), 7.24(\mathrm{~s}, \mathrm{NH}), 7.58(\mathrm{brs}, 4 \mathrm{H}, \mathrm{ArH})$. ${ }^{13} \mathrm{C} \mathrm{NMR}\left(\mathrm{CDCl}_{3}, 75.5 \mathrm{MHz}\right): 14.4\left(\mathrm{CH}_{2}\right), 22.5\left(\mathrm{CH}_{2}\right), 25.6\left(\mathrm{CH}_{2}\right), 28.9\left(\mathrm{CH}_{2}\right), 29.1\left(\mathrm{CH}_{2}\right), 31.6\left(\mathrm{CH}_{2}\right)$, $36.8\left(\mathrm{CH}_{2}\right), 54.1\left(\mathrm{CH}_{2}\right), 119.9(\mathrm{ArCH}), 120.1(\mathrm{ArCH}), 124.3(\mathrm{C}), 133.8(\mathrm{C}), 136.7(\mathrm{C}), 141.6(\mathrm{C}), 162.2(\mathrm{C})$, 171.7 (C=O); IR (ATR): $v_{\max } 3338.9,2915.7,1678.1,1521.3,1285.3,1156.1,931.4,822.9 ; \mathrm{UV}(\mathrm{MeOH}): \lambda_{\max }$ $290.0 \mathrm{~nm}\left(\varepsilon 5982.4 \mathrm{~cm}^{-1} \mathrm{M}^{-1}\right)$; HRMS (ESI) $\mathrm{m} / z$ calcd. for $\mathrm{C}_{18} \mathrm{H}_{22} \mathrm{Cl}_{2} \mathrm{~N}_{2} \mathrm{O}_{2} \mathrm{Na}_{1} 391.0951[\mathrm{M}+\mathrm{Na}]^{+}$, found 391.0952 .

(34) 2-(4-bromophenyl)-N-(4-(3,4-dichloro-2-oxo-2,5-dihydro-1H-pyrrol-1-yl)phenyl)acetamide (42)<smiles>O=C(Cc1ccc(Br)cc1)Nc1ccc(N2CC(Cl)=C(Cl)C2=O)cc1</smiles>

The title compound was prepared according to method $C$ from amine 1-(4-aminophenyl)-3, 4-dichloro-1,5-dihydro-2H-pyrrol-2-one (23) (200 mg, $0.82 \mathrm{mmol})$ and 2-(4-bromophenyl)acetic acid (110.7 $\mathrm{mg}, 0.82 \mathrm{mmol}$ ). The latter was first converted to the corresponding acid chloride prior to amide coupling by treatment with thionyl chloride $(2 \mathrm{~h})$ on reflux, followed by complete dryness in high vac. After completion of the reaction, the crude mixture was evaporated to complete dryness, followed by trituration from methanol, and the obtained solid was then washed twice with $1 \mathrm{~mL}$ of ether. The solid was collected by filtration and dried in high vac. A white solid (100 mg; 32\%) was obtained; m.p. 159.2 ${ }^{\circ} \mathrm{C} ;{ }^{1} \mathrm{H}$ NMR $\left(\mathrm{CDCl}_{3}, 300 \mathrm{MHz}\right): 3.64\left(\mathrm{~s}, 2 \mathrm{H}, \mathrm{CH}_{2}\right), 4.82\left(\mathrm{~s}, 2 \mathrm{H}, \mathrm{C}_{-}-\mathrm{CH}_{2}\right), 7.30(\mathrm{~d}, J=8.2 \mathrm{~Hz}, 2 \mathrm{H}, \mathrm{ArH})$, 
$7.52(\mathrm{~d}, J=8.2 \mathrm{~Hz}, 2 \mathrm{H}, \mathrm{ArH}), 7.63$ (brs, $4 \mathrm{H}, \mathrm{ArH}), 10.33$ (s, NH). ${ }^{13} \mathrm{C} \mathrm{NMR}\left(\mathrm{CDCl}_{3}, 75.5 \mathrm{MHz}\right): 45.95$ $\left(\mathrm{CH}_{2}\right), 54.09\left(\mathrm{CH}_{2}\right), 120.06(\mathrm{ArCH}), 120.21(\mathrm{ArCH}), 124.3(\mathrm{C}), 131.6(\mathrm{ArCH}), 131.9(\mathrm{ArCH}), 134.1(\mathrm{C})$, 135.85 (C), 136.40 (C), 141.7 (C), 162.3 (C), 169.0 (C); IR (ATR): $v_{\max } 3279.8,2978.7,1690.5,1516.5,1379.5$, 1153.7, 927.8, 824.9; UV (MeOH): $\lambda_{\max } 285.0 \mathrm{~nm}\left(\varepsilon 3375.7 \mathrm{~cm}^{-1} \mathrm{M}^{-1}\right)$; HRMS (ESI) $m / z$ calcd. for $\mathrm{C}_{18} \mathrm{H}_{13} \mathrm{Br}_{1} \mathrm{Cl}_{2} \mathrm{~N}_{2} \mathrm{O}_{2} \mathrm{Na}_{1} 460.9430[\mathrm{M}+\mathrm{Na}]^{+}$, found 460.9431 .

\subsection{Biology}

\subsubsection{Quorum Sensing Inhibition Assay for PAMH602}

The P. aeruginosa MH602 PlasB::gfp (ASV) reporter strain was used. An overnight culture was prepared in Luria-Bertani (LB10) media supplemented with gentamycin $(40 \mu \mathrm{M})$. This bacterial culture solution was diluted (1 in 100) with LB10 supplemented with gentamycin $(15 \mu \mathrm{M})$. Stock solutions of the synthesized compounds were prepared at $20 \mathrm{mM}$ in DMSO. Compounds were pipetted into each well with final concentrations of $250 \mu \mathrm{M}, 125 \mu \mathrm{M}$ and $62.5 \mu \mathrm{M}$ (in triplicate) with a final volume of $200 \mu \mathrm{L}$ with the prepared bacterial culture. The negative control was prepared containing $200 \mu \mathrm{L}$ of the bacterial culture without the tested compounds. The halogenated furanone (Fu-30) 5 and TP- 5 were used as positive controls. The plates were incubated at $37^{\circ} \mathrm{C}$ for $15 \mathrm{~h}$. The plates were measured for GFP expression (fluorescence: excitation $485 \mathrm{~nm}$, emission $535 \mathrm{~nm}$ ) using a microplate reader (Wallac Victor, Perkin-Elmer), and the cell growth was also assessed by recording the OD at $600 \mathrm{~nm}$.

\subsubsection{Pyocyanin Assay}

An overnight culture of $P$. aeruginosa PAO1 was diluted 1 in 100 with LB10 medium. To a 5-mL test tube were added the tested compounds (compounds prepared from a DMSO stock of $20 \mathrm{mM}$ ), and $2.5 \mathrm{~mL}$ of the prepared culture was added, giving final concentrations of $250 \mu \mathrm{M}$ and $32 \mu \mathrm{M}$. An equivalent amount of DMSO was prepared for the positive control containing the bacterial culture without the tested compounds. The same medium without bacterial culture in an equivalent amount of DMSO was used as the background reading. The cultures were grown with shaking at $37^{\circ} \mathrm{C}$ for $17 \mathrm{~h}$. The final cell density was measured by reading the absorbance at $600 \mathrm{~nm}\left(\mathrm{OD}_{600}\right)$, and the solutions were then centrifuged for $5000 \mathrm{rpm}$. The clear supernatant was then transferred by pipetting into a plastic 96-well plate, and the absorbance was measured at $695 \mathrm{~nm}$.

\subsection{Docking}

The crystal structure of LasR complexed with OdDHL (PDB: 2UV0) was used. The protein was prepared before docking by removing the other subunits, and only subunit $\mathrm{E}$ was used for docking based on a previous control docking. The binding site and cavity were prepared as follows. Water molecules and ligands including the LasR bound ligand in the binding pocket were removed, and the crystal structure was protonated. The binding pocket was chosen from the 'receptor cavities' tool, and this defined the binding site sphere in the proposed pocket. Alternate conformers were identified (Ser20 and Ser131), but were outside the binding pocket sphere. The geometry of the protonated OdDHL ligand was optimized with the CHARMM force field [28], and it was docked back to the prepared protein using the Genetic Optimization for Ligand Docking (GOLD) algorithm, Versions 5.2.1, 5.2.2, and 5.4.0 (Cambridge Crystallographic Data Centre, U.K.) [29]. The number of the docking runs was set to 100 , while the 'detect cavity' and 'early determination' were set to 'false', but all other parameters were set to their defaults. The GoldScore was specified as the fitness score function. After the docking run, ligand poses were analysed based on their clusters using the RMSD of heavy atoms and within each cluster; poses were ranked in order of decreasing GoldScore value. The largest clusters at RMSD of around $2 \AA$ were usually considered. The best pose of the largest cluster for OdDHL when docked back to the prepared protein was selected. The ligand from the crystal structure was superimposed with the selected pose, and an acceptable RMSD was obtained of $0.94 \AA$ (heavy atoms). 
The tested compounds were sketched, protonated and their energy minimized as above with the CHARMm force field [28]. Docking was then performed and analysed as described above. Receptor ligand interactions of selected poses were analysed using the 'view interactions' tool. Different types of interactions including hydrogen bonds, hydrophobic and $\pi$-interactions were examined and compared to the crystal structure. Any other attractive forces, repulsive or unfavourable interactions were noted.

Supplementary Materials: The growth inhibition, full docking and spectral data are provided in the Supplementary.

Author Contributions: N.K., R.G., D.S.B., G.I. and K.K.K.H. planned and designed the experiments. B.A., S.N. and N.N.B. provided the data from biology screening. B.A. and D.S.W. performed the docking study and analysed and interpreted the data. B.A. and A.T., performed the chemistry experiments and analysed and interpreted the data. B.A. wrote the paper. S.A.R. provided the bacterial strains and assistance with biology. N.K. supported financially.

Acknowledgments: We thank the NMR and BMSF facility, UNSW. The authors would like to acknowledge the Saudi Ministry of Education and King Khalid University for an Endowment Fund and financial support given to B. Almohaywi.

Conflicts of Interest: The authors declare no conflict of interest.

\section{References}

1. Levy, S.B.; Marshall, B. Antibacterial resistance worldwide: Causes, challenges and responses. Nat. Med. 2004, 10, S122-S129. [CrossRef] [PubMed]

2. Raffa, R.B.; Iannuzzo, J.R.; Levine, D.R.; Saeid, K.K.; Schwartz, R.C.; Sucic, N.T.; Terleckyj, O.D.; Young, J.M. Bacterial communication ("quorum sensing") via ligands and receptors: A novel pharmacologic target for the design of antibiotic drugs. J. Pharmacol. Exp. Ther. 2005, 312, 417-423. [CrossRef] [PubMed]

3. Hodgkinson, J.T.; Welch, M.; Spring, D.R. Learning the language of bacteria. ACS Chem. Biol. 2007, 2, 715-717. [CrossRef] [PubMed]

4. Fuqua, C.; Parsek, M.R.; Greenberg, E.P. Regulation of gene expression by cell-to-cell communication: Acyl-homoserine lactone quorum sensing. Annu. Rev. Genet. 2001, 35, 439-468. [CrossRef] [PubMed]

5. Lowery, C.A.; Salzameda, N.T.; Sawada, D.; Kaufmann, G.F.; Janda, K.D. Medicinal chemistry as a conduit for the modulation of quorum sensing. J. Med. Chem. 2010, 53, 7467-7489. [CrossRef] [PubMed]

6. Hentzer, M.; Wu, H.; Andersen, J.B.; Riedel, K.; Rasmussen, T.B.; Bagge, N.; Kumar, N.; Schembri, M.A.; Song, Z; Kristoffersen, P. Attenuation of pseudomonas aeruginosa virulence by quorum sensing inhibitors. EMBO J. 2003, 22, 3803-3815. [CrossRef] [PubMed]

7. Fuqua, C.; Greenberg, E.P. Listening in on bacteria: Acyl-homoserine lactone signalling. Nat. Rev. Mol. Cell Biol. 2002, 3, 685-695. [CrossRef] [PubMed]

8. Moore, J.D.; Rossi, F.M.; Welsh, M.A.; Nyffeler, K.E.; Blackwell, H.E. A comparative analysis of synthetic quorum sensing modulators in pseudomonas aeruginosa: New insights into mechanism, active efflux susceptibility, phenotypic response, and next-generation ligand design. J. Am. Chem. Soc. 2015, 137, 14626-14639. [CrossRef] [PubMed]

9. LaSarre, B.; Federle, M.J. Exploiting quorum sensing to confuse bacterial pathogens. Microbiol. Mol. Biol. Rev. 2013, 77, 73-111. [CrossRef] [PubMed]

10. Müh, U.; Hare, B.J.; Duerkop, B.A.; Schuster, M.; Hanzelka, B.L.; Heim, R.; Olson, E.R.; Greenberg, E.P. A structurally unrelated mimic of a pseudomonas aeruginosa acyl-homoserine lactone quorum-sensing signal. Proc. Natl. Acad. Sci. USA 2006, 103, 16948-16952. [CrossRef] [PubMed]

11. Manefield, M.; Nys, R.D.; Kumar, N.; Roger, R.; Givskov, M.; Steinberg, P.; Kjelleberg, S. Evidence that halogenated furanones from delisea pulchra inhibit acylated homoserine lactone (ahl)-mediated gene expression by displacing the ahl signal from its receptor protein. Microbiology 1999, 145, 283-291. [CrossRef] [PubMed]

12. Kumar, N.; Iskander, G. Novel Lactams. Patent WO 2,007,085,042, 2 August 2007.

13. Goh, W.-K.; Gardner, C.R.; Sekhar, K.V.C.; Biswas, N.N.; Nizalapur, S.; Rice, S.A.; Willcox, M.; Black, D.S.; Kumar, N. Synthesis, quorum sensing inhibition and docking studies of 1,5-dihydropyrrol-2-ones. Bioorg. Med. Chem. 2015, 23, 7366-7377. [CrossRef] [PubMed] 
14. Zhang, J.; Blazecka, P.G.; Davidson, J.G. First direct reductive amination of mucochloric acid: A simple and efficient method for preparing highly functionalized $\alpha, \beta$-unsaturated $\gamma$-butyrolactams. Org. Lett. 2003, 5, 553-556. [CrossRef] [PubMed]

15. Pereira, U.A.; Barbosa, L.C.A.; Maltha, C.R.A.; Demuner, A.J.; Masood, M.A.; Pimenta, A.L. $\gamma$-alkylidene$\gamma$-lactones and isobutylpyrrol-2(5h)-ones analogues to rubrolides as inhibitors of biofilm formation by gram-positive and gram-negative bacteria. Bioorg. Med. Chem. Lett. 2014, 24, 1052-1056. [CrossRef] [PubMed]

16. Kayumov, A.R.; Khakimullina, E.N.; Sharafutdinov, I.S.; Trizna, E.Y.; Latypova, L.Z.; Lien, H.T.; Margulis, A.B.; Bogachev, M.I.; Kurbangalieva, A.R. Inhibition of biofilm formation in bacillus subtilis by new halogenated furanones. J. Antibiot. 2015, 68, 297-301. [CrossRef] [PubMed]

17. Bellina, F.; Anselmi, C.; Martina, F.; Rossi, R. Mucochloric acid: A useful synthon for the selective synthesis of 4-aryl-3-chloro-2( $5 H$ )-furanones,(z)-4-aryl-5-[1-(aryl) methylidene]-3-chloro-2(5H)-furanones and 3,4-diaryl-2(5H)-furanones. Eur. J. Org. Chem. 2003, 2003, 2290-2302. [CrossRef]

18. Guerrero, M.D.; Aquino, M.; Bruno, I.; Terencio, M.C.; Paya, M.; Riccio, R.; Gomez-Paloma, L. Synthesis and pharmacological evaluation of a selected library of new potential anti-inflammatory agents bearing the $\gamma$-hydroxybutenolide scaffold: A new class of inhibitors of prostanoid production through the selective modulation of microsomal prostaglandin e synthase-1 expression. J. Med. Chem. 2007, 50, 2176-2184. [CrossRef] [PubMed]

19. Pereira, U.A.; Barbosa, L.C.; Demuner, A.J.; Silva, A.A.; Bertazzini, M.; Forlani, G. Rubrolides as model for the development of new lactones and their aza analogs as potential photosynthesis inhibitors. Chem. Biodivers. 2015, 12, 987-1006. [CrossRef] [PubMed]

20. Barbosa, L.C.; Maltha, C.L.R.; Lage, M.R.; Barcelos, R.C.; Donà, A.; Carneiro, J.W.; Forlani, G. Synthesis of rubrolide analogues as new inhibitors of the photosynthetic electron transport chain. J. Agric. Food Chem. 2012, 60, 10555-10563. [CrossRef] [PubMed]

21. Das Sarma, K.; Zhang, J.; Huang, Y.; Davidson, J.G. Amino acid esters and amides for reductive amination of mucochloric acid: Synthesis of novel $\gamma$-lactams, short peptides and antiseizure agent levetiracetam (keppra ${ }^{\circledR}$ ). Eur. J. Org. Chem. 2006, 2006, 3730-3737. [CrossRef]

22. Hentzer, M.; Riedel, K.; Rasmussen, T.B.; Heydorn, A.; Andersen, J.B.; Parsek, M.R.; Rice, S.A.; Eberl, L.; Molin, S.; Høiby, N. Inhibition of quorum sensing in pseudomonas aeruginosa biofilm bacteria by a halogenated furanone compound. Microbiology 2002, 148, 87-102. [CrossRef] [PubMed]

23. Defoirdt, T.; Brackman, G.; Coenye, T. Quorum sensing inhibitors: How strong is the evidence? Trends Microbiol. 2013, 21, 619-624. [CrossRef] [PubMed]

24. Miller, L.C.; O’Loughlin, C.T.; Zhang, Z.; Siryaporn, A.; Silpe, J.E.; Bassler, B.L.; Semmelhack, M.F. Development of potent inhibitors of pyocyanin production in pseudomonas aeruginosa. J. Med. Chem. 2015, 58, 1298-1306. [CrossRef] [PubMed]

25. O'Loughlin, C.T.; Miller, L.C.; Siryaporn, A.; Drescher, K.; Semmelhack, M.F.; Bassler, B.L. A quorum-sensing inhibitor blocks pseudomonas aeruginosa virulence and biofilm formation. Proc. Natl. Acad. Sci. USA 2013, 110, 17981-17986. [CrossRef] [PubMed]

26. Bottomley, M.J.; Muraglia, E.; Bazzo, R.; Carfi, A. Molecular insights into quorum sensing in the human pathogen pseudomonas aeruginosa from the structure of the virulence regulator lasr bound to its autoinducer. J. Biol. Chem. 2007, 282, 13592-13600. [CrossRef] [PubMed]

27. Gerdt, J.P.; McInnis, C.E.; Schell, T.L.; Blackwell, H.E. Unraveling the contributions of hydrogen-bonding interactions to the activity of native and non-native ligands in the quorum-sensing receptor lasr. Org. Biomol. Chem. 2015, 13, 1453-1462. [CrossRef] [PubMed]

28. Momany, F.A.; Rone, R. Validation of the general purpose quanta ${ }^{\circledR} 3.2 /$ charmm $^{\circledR}$ force field. J. Comput. Chem. 1992, 13, 888-900. [CrossRef]

29. Jones, G.; Willett, P.; Glen, R.C.; Leach, A.R.; Taylor, R. Development and validation of a genetic algorithm for flexible docking. J. Mol. Biol. 1997, 267, 727-748. [CrossRef] [PubMed]

Sample Availability: Samples of Compounds 12, 13, 19, 23 and 24 are available from the authors. 